\title{
Potato Resistance to Insects
}

\section{Yvan Pelletier $^{1 *}$ • Finbarr G. Horgan ${ }^{2}$ • Julien Pompon ${ }^{1,3}$}

\author{
1 Potato Research Centre, Agriculture and Agri-Food Canada, Fredericton, NB, E3B 4Z7, Canada \\ 2 Crop and Environmental Sciences Division, International Rice Research Institute, DAPO Box 7777, Metro Manila, The Philippines \\ 3 Department of Biology, University of New Brunswick, Fredericton, NB, E3B 5A3, Canada \\ Corresponding author: * yvan.pelletier@agr.gc.ca
}

\begin{abstract}
Potato, Solanum tuberosum, is the fourth major crop and is grown around the world. It is subject to a large number of insect pests, but the Colorado potato beetle, the potato tuber moths and aphids are the most damaging. Crop resistance to these insects can alleviate problems caused by the use of synthetic insecticides. The diversity of wild tuber-bearing Solanum species offers a source of resistance to insects and pathogens; however, it has so far been under-utilized. This article reviews progress made in the development of insect resistant potato cultivars, as well as the biological and methodological challenges of developing insect resistant potato varieties. We conclude that the prospects of using wild species in future potato breeding programs are good, but, screening and experimental protocols need to be more holistic given the complexity of insect-potato interactions.
\end{abstract}

Keywords: aphids, Colorado potato beetle, crop resistance, Leptinotarsa decemlineata, Macrosiphum euphorbiae, Myzus persicae, potato tuber moth, Phthorimaea operculella, Solanum tuberosum, Symmetrischema tangolias, Tecia solanivora Abbreviations: CPB, Colorado potato beetle; EPG, electric penetration graph; QTL, quantitative trait locus

\section{CONTENTS}

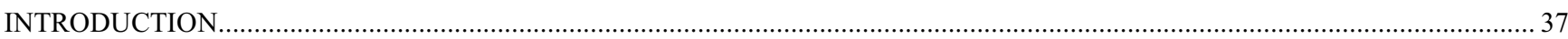

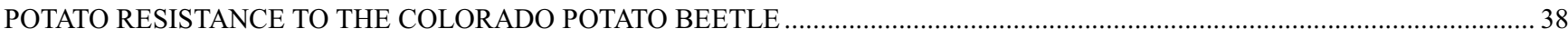

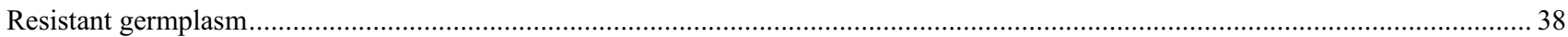

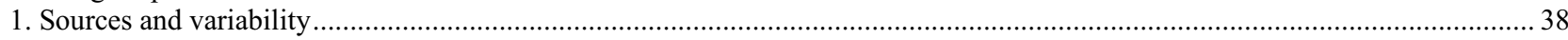

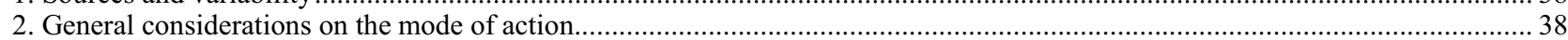

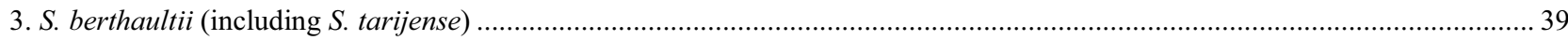

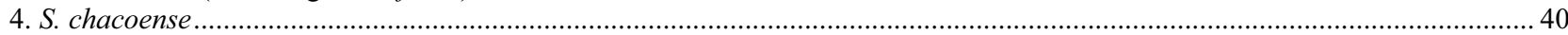

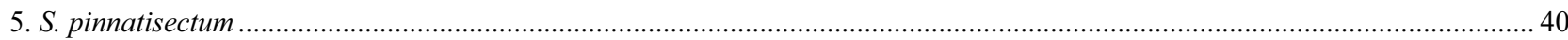

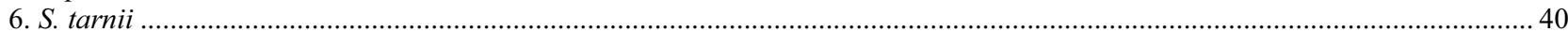

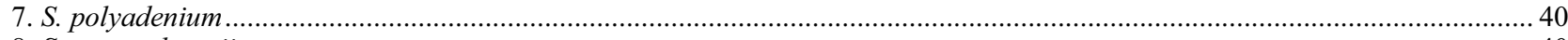

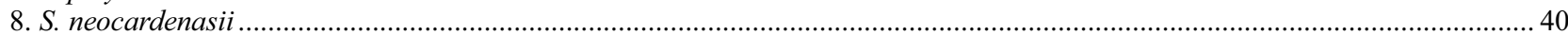

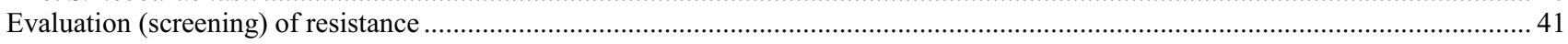

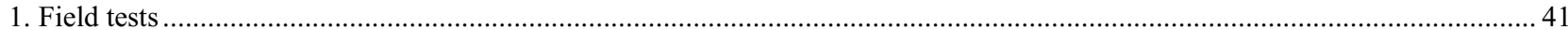

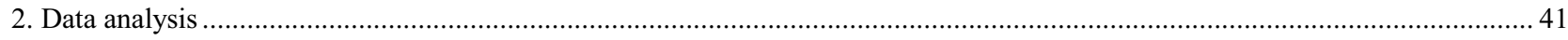

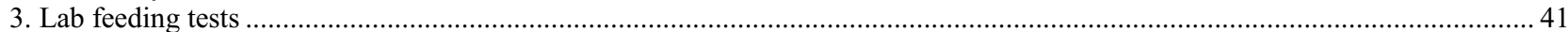

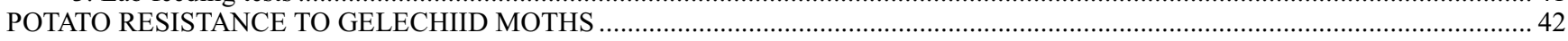

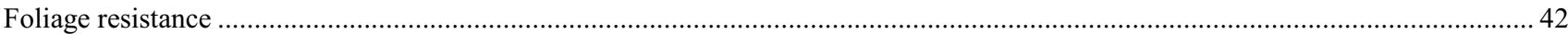

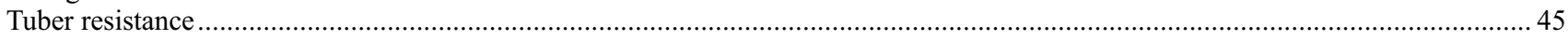

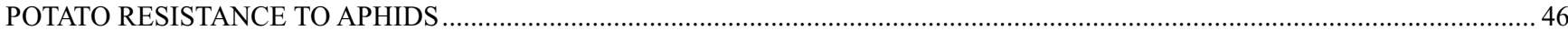

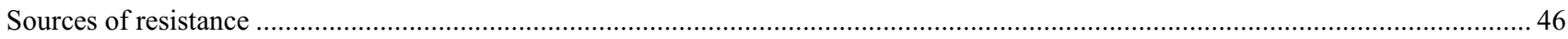

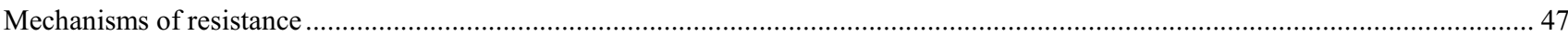

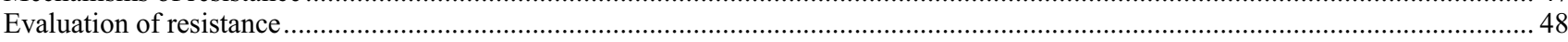

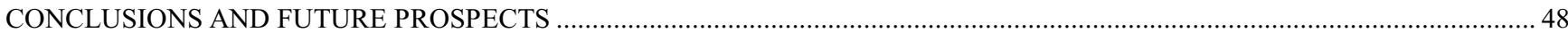

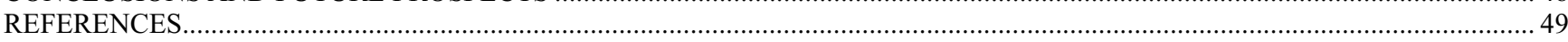

\section{INTRODUCTION}

The development of agriculture has been based on the development of crop genotypes with good yield that are well adapted to the biotic and abiotic conditions encountered in the regions where they are grown. Producers have been genetically enhancing the ability of crops to resist insects and diseases by keeping the most resistant individuals of production for planting the next season. This process became better understood with the development of modern population and molecular genetics. More recently, approaches to breeding for insect resistance in crops have become more closely matched to underlying genetic models (Painter 1951).

There are numerous examples of the successful use of insect resistant crops in agriculture, such as wheat cultivars with resistance to the Hessian fly or phylloxera resistant grapevines, some of which date back over 200 years (Smith and Quisenberry 1994). These successes demonstrate the potential of crop resistance to reduce the economic impact of insects. However, in an era where chemical insecticides are increasingly effective and accessible, direct insect dam- 
age to crops is often perceived to be under total control. However, insecticide control has a range of associated problems including the development of insecticide resistance, increased concerns about the use of petroleum derived products, direct effects on the environment, and possible deleterious effects on the health of users. Crop resistance to insects is seen as an environmentally friendly and sustainable solution to insect pests that could reduce the inputs of chemical insecticides. Recent evidence suggests that growers are increasingly interested in incorporating crop resistance into their integrated pest management strategies (Smith and Quisenberry 1994).

Potato, Solanum tuberosum, is the fourth major crop, is grown around the world, and is attacked by a diversity of insect pests. Modern potato varieties have a narrow genetic base and, as a consequence, are usually equally susceptible to most herbivores (Jansky et al. 2009). Many insect resistance traits can be imported into cultivated varieties from wild potato relatives. Fortunately, potato breeders have approximately 230 species of wild potato relatives (Solanaceae, Section Petota) to choose from when searching for desirable resistance traits (Flanders et al. 1999). Wild potatoes are native to the area from the southwestern United States, southward through Mexico and Central America, along the Andes of South America, and into the plains of Argentina, Paraguay, and Uruguay. Most species have a narrow range defined by a specific set of ecogeographic characteristics, but some are more widely distributed. Representative material is available to scientists as continuously maintained accessions in international genebanks. These genebanks also maintain information on different aspects of the accessions including resistance levels to insects (Flanders et al. 1999).

The majority of wild Solanum species, approximately $64 \%$, are diploid $(2 \mathrm{x}=24)$, and most of the remaining species are either tetraploid $(4 \mathrm{x}=48)$ or hexaploid $(6 \mathrm{x}=72)$ (Jansky et al. 2009). Crossability between wild species or with cultivated varieties is mainly determined by having the proper balance of genetic factors contributed by gametes to the endosperm, described by the endosperm balance number. Solanum species have consequently been assigned endosperm balance numbers based on their ability to hybridize with each other (Jansky et al. 2009). Furthermore, somatic hybridization can be used to overcome the lack of compatibility between wild and cultivated potatoes (Chen et al. 2008).

\section{POTATO RESISTANCE TO THE COLORADO POTATO BEETLE}

The Colorado potato beetle (CPB) has become a major pest of potato around the world. Originally feeding on a few Solanaceous plant species, it rapidly adapted to potato and spread to many of the regions where the crop is produced. Its biology has been extensively studied (Hare 1990). The fact that both the adult and the larval stages feed on the potato crop is important for the development of insect resistant potatoes. Adults are mobile and have to find a source of food after emerging from hibernation or after moulting in the ground. Oviposition is generally preceded by feeding on a host plant. The first instar larvae are small and tend to remain on the plant material where the eggs were deposited. On a susceptible host plant, adults limit egg numbers according to the capacity of the plant to support feeding by the larvae (Pelletier 1995). Older larvae are more mobile but rarely have to move to another plant to complete their development. Acceptance of the plant as a host is determined by two events: adult choice and establishment by first instar larvae.

\section{Resistant germplasm}

\section{Sources and variability}

Some differences in the biological performance of the CPB have been observed among commercial potato cultivars (Torka 1950; Horton et al. 1997; Metspalu et al. 2000), but, resistance has not been at a level that eliminates economic impact on the crop. Furthermore, differences in foliar glycoalkaloids are not correlated with negative effects on the biological performance of the CPB (Metspalu et al. 2000; Lyytinen et al. 2007), suggesting that it is necessary to look for resistance sources outside the cultivated potato germplasm.

Between 1966 and 1986, large-scale screening for resistance to the CPB was conducted in Minnesota providing information on 1686 potato accessions representing 100 species of wild Solanum (Flanders et al. 1992). Other studies have also assessed resistance levels, but have used substantially fewer species and genotypes (Torka 1950; Carter 1987; Jansky et al. 2009). This information has guided the selection of parents for the development of resistant potato cultivars. These studies also demonstrated the variability of resistance within species, and between accessions within the same species (Carter 1987; Jansky et al. 2009). Studies conducted at the genotype level (within accessions) provided evidence that resistance varies within accessions, that this variability differs depending on the accession and the species in question, and that it is generally small enough not to greatly influence the development of breeding populations (Bamberg et al. 1996; Pelletier and Tai 2001; Pelletier et al. 2001). However, fine screening of accessions is recommended if a single genotype is to be used as a parent.

The crossability of wild Solanum species with the cultivated potato depends on the difference between the two species for several factors including ploidy and the endosperm balance number, but, interspecific crossing is generally more successful where the wild species is closely related to potato (Jackson and Hanneman 1999). Protoplasm fusion is often the only way to introgress the resistance trait of the wild Solanum species into potato germplasm (Xu et al. 1991; Chen et al. 2004). This method increases the number of candidate species that could be used as resistant parents for breeding CPB resistant cultivars. However, the number of CPB resistant species currently used in breeding programs is limited (see below). These and other species (currently not used in breeding programs) have been used to determine host effects on biological performance of the beetle (Table 1).

\section{General considerations on the mode of action}

Wild and cultivated potatoes contain a variety of glycoalkaloids that are considered protective factors against herbivores. However, total glycoalkaloid levels as well as the concentrations of the most abundant glycoalkaloids are not associated with resistance to the CPB (Flanders et al. 1992). Some specific glycoalkaloids like commersonine, dehydrocommersonine, demissine, and leptines, when present in the foliage even in relatively low concentrations, provide better protection than total glycoalkaloid content. Breeding for glycoalkaloid content, as was done for leptines from $S$. chacoense, is relatively difficult since the trait is polygenic, foliage glycoalkaloid content is correlated with tuber content (except for leptines), and glycoalkaloid production is influenced by environmental factors (Tingey 1984).

Wild Solanum species also possess trichomes that are generally considered to form a protective barrier against insect herbivory. Species with glandular trichomes were found to be more frequently resistant to the CPB and to some other insects than species without glandular-trichomes (Flanders et al. 1992). In potatoes, glandular trichomes are of two types: type-A glandular trichomes are four-lobed, and contain phenolic compounds; type-B are longer trichomes which exude droplets containing sucrose esters of carboxylic acids from their tips (Flanders et al. 1992). The presence or density of glandular trichomes does not entirely explain observed differences in resistance levels in potatoes. In some cases it is the nature of the exudates that plays a determining role in providing resistance. The role of glan- 
Table 1 List of wild Solanum species that were studied for their effects on the biological performance of the CPB.

\begin{tabular}{|c|c|}
\hline Species & References \\
\hline S. acroglossum & Pelletier et al. 2007 \\
\hline S. allandiae & Carter 1987 \\
\hline S. berthaultii & $\begin{array}{l}\text { Gibson 1979; Casagrande 1982; Mehlenbacher et al. 1984; Wright et al. 1985; Gregory et al. 1986; Groden and Casagrande 1986; } \\
\text { Carter 1987; Dimock and Tingey 1987; Castanera et al. 1988; Neal et al. 1989; Pelletier and Smilowitz 1990; Neal et al. 1991; } \\
\text { Pelletier and Smilowitz 1991; Steffens and Walters 1991; Flanders et al. 1992; Franca and Tingey 1994; Tingey and Yencho 1994; } \\
\text { Yencho and Tingey 1994; Yencho et al. 1994; Castanera et al. 1996; Smilyanets et al. 1996; Sikinyi et al. 1997; Pelletier et al. 1999; } \\
\text { Pelletier and Tai 2001; Pelletier and Dutheil 2006; Smilyanets et al. } 2007\end{array}$ \\
\hline S. brevicaule & Smilyanets et al. 2007 \\
\hline S. bukasovii & Carter 1987; Smilyanets et al. 2007 \\
\hline S. capsicibaccatum & Sikinyi et al. 1997; Pelletier et al. 1999; Pelletier and Tai 2001; Pelletier and Clark 2004 \\
\hline S. chacoense & $\begin{array}{l}\text { Torka 1950; Hawkes 1958; Sinden et al. 1986; Carter 1987; Sagredo et al. 1988; Flanders et al. 1992; Sikinyi et al. 1997; Sanford et } \\
\text { al. 1998; Yencho et al. 2000; Sagredo et al. 2006; Smilyanets et al. } 2007\end{array}$ \\
\hline S. chomatophilum & Pelletier et al. 2007 \\
\hline S. comersonii & Hawkes 1958; Flanders et al. 1992 \\
\hline S. fendleri & Carter 1987; Lorenzen and Balbyshev 1997 \\
\hline S. jamesii & Hawkes 1958; Carter 1987; Pelletier et al. 1999, 2001 \\
\hline S. neocardenasii & Dimock et al. 1986; Sinden et al. 1991 \\
\hline S. okadae & Pelletier et al. 1999; Pelletier et al. 2001; Pelletier and Clark 2004 \\
\hline S. oplocense & Pelletier et al. 2001; Pelletier and Clark 2004 \\
\hline S. parodie & Smilyanets et al. 2007 \\
\hline S. paucissestum & Pelletier et al. 2007 \\
\hline S. pinnatisectum & Carter 1987; Sinden et al. 1991; Pelletier et al. 1999, 2001; Chen et al. 2004; Pelletier and Clark 2004 \\
\hline S. piurae & Pelletier et al. 2007 \\
\hline S. polyadenium & Gibson 1976b; Carter 1987; Pelletier and Tai 2001; Pelletier and Clark 2004 \\
\hline S. raphanifolium & Sikinyi et al. 1997 \\
\hline S. rybinii & Smilyanets et al. 2007 \\
\hline S. schiskii & Smilyanets et al. 2007 \\
\hline S. stoloniferum & Hawkes 1958; Carter 1987 \\
\hline S. sucrense & Carter 1987 \\
\hline S. tarnii & Pelletier et al. 2007; Thieme et al. 2008 \\
\hline S. trifidum & Sikinyi et al. 1997; Pelletier et al. 1999; Pelletier and Tai 2001; Pelletier and Clark 2004 \\
\hline
\end{tabular}

dular trichomes has mainly been studied with $S$. berthaultii (including $S$. tarijense).

\section{S. berthaultii (including S. tarijense)}

S. tarijense and $S$. berthaultii were initially described by Hawkes as different species, but have since been reclassified as one species, S. berthaultii (Spooner et al. 2007). The main taxonomic difference between the two former species was the lack of type-B trichomes in S. tarijense; however, some accessions labeled as $S$. berthaultii also do not bear type-B trichomes (Pelletier and Smilowitz 1991; Spooner et al. 2007). Most of the literature on potato resistance to the CPB is related to those $S$. berthaultii accessions that bear type-B trichomes. Host acceptance and performance of the CPB differ widely even among those accessions that always bear type-B trichomes.

Several authors have demonstrated a reduction in biological performance of the CPB at the larval and the adult stages when confined on $S$. berthaultii (Casagrande 1982; Wright et al. 1985; Groden and Casagrande 1986; Neal et al. 1991). This reduction in biological performance was associated with the presence of trichomes and their exudates. Exudate from type-A trichomes, containing polyphenol oxidase (Castanera et al. 1996), accumulates on the tarsae of small beetle larvae leading to reduced survival (Dimock and Tingey 1987; Neal et al. 1991) and reduced leaf consumption (Dimock and Tingey 1988). The ability of $S$. berthaultii to entrap small insects or the appendages of larger ones comes from the reaction of the sticky exudates of type-B trichomes, which contain sesquiterpenoid and sucrose esters (Neal et al. 1989), and the polyphenoloxidase contained in type-A trichomes, resulting in quinone formation (Gregory et al. 1986; Steffens and Walters 1991). Trichomes also influence beetle preferences among $S$. berthaulti genotypes: Given a feeding choice between $S$. tuberosum and $S$. berthaultii, larvae and adults preferred the foliage of $S$. tuberosum, but adults were more discriminating (Yencho and Tingey 1994). Adult beetles were less attracted to intact leaflets of $S$. berthaultii, or $S$. tuberosum leaflets to which trichome exudates from $S$. berthaultii had been transferred, than to $S$. berthaultii foliage with the trichomes removed (Yencho and Tingey 1994). A leaf extract containing type-B trichome exudates, but not a similar extract from a resistant $S$. berthaultii without type-B trichomes, applied to potato reduced feeding by adult CPB (Pelletier and Smilowitz 1990). Extracts from a $S$. berthaultii clone bearing type-B trichomes when applied to potato foliage did not modify the behavior of adult CPB but reduced consumption while similar extracts from another genotype of $S$. berthaultii without type-B trichomes increased movement of the adults and reduced contact with the plant material (Pelletier and Smilowitz 1991).

However the effects of trichome exudates do not entirely explain the resistance of $S$. berthaultii. The removal of trichome exudates improves feeding by small larvae but does not improve biological performance of the larvae (Dimock and Tingey 1988; Neal et al. 1989). S. berthaultii foliage, when ingested by the CPB, reduced ovarian development and fecundity. Large amounts of undigested material found in the midgut of the insects suggest that $S$. berthaultii could negatively influence digestion, being a poor nutritional source for the beetle (Franca and Tingey 1994).

Solanum tarijense (mainly $S$. berthaultii accessions without type-B trichomes) has also been identified as resistant (Flanders et al. 1992); however only a few studies have ever tried to characterize the factors involved in its observed resistance to the CPB. S. tarijense negatively impacts the biological performance of the CPB but has a more pronounced effect on the adults (Pelletier et al. 2001; Smilyanets et al. 2007). Thanatosis reaction is observed in adults deposited on $S$. tarijense foliage; This reaction is greatly reduced when type-A trichomes are removed, but feeding remains low; The volatile fraction of methylene chloride dip extracts from $S$. tarijense has been shown to act as a feeding deterrent when applied to potato foliage and changes host selection behavior of adult beetles (Pelletier and Dutheil 2006). 
Effort has been made to isolate the chemicals responsible for non-trichome based resistance factor(s) in S. berthaultii. Bioassay-guided fractionation of methylene chloride leaf rinse extracts lead to the isolation of a polar fraction with low deterrent activity and two nonpolar fractions exhibiting higher specific activity (Yencho et al. 1994). The nonvolatile fraction of the extract had more deterrent activity than the volatile fraction.

The variability of resistance levels between $S$. berthaultii accessions, and the prospect of using this plant as a source of resistance has brought questions as to the ability of the CPB to overcome resistance. When confined on $S$. berthaultii, oviposition and larval mortality of the CPB was no longer reduced after two and three generations respectively (Groden and Casagrande 1986). A significant additive genetic component was found when CPB was raised on $S$. berthaultii, indicating the possibility of adaptation of the insect to the wild Solanum while maintaining its biological fitness on potato (Pelletier and Smilowitz 1991). An artificial selection study comparing insects grown on potato and on $S$. berthaultii for 10 generations did not produce a significant change in the net replacement rate between the two strains (Franca et al. 1994).

Trichome composition varies according to the environment where the accession was originally collected (Gibson 1979). The presence of type-B trichomes is genetically controlled by a single dominant gene (Gibson 1979). The heritability of trichome-related traits measured in a population of $S$. berthaultii $\times S$. tuberosum hybrids was variable; Droplet size of type-B trichome exudates was highly heritable $(64 \pm 8 \%)$, the density of type-B trichomes intermediate $(22$ $\pm 5 \%)$ and the heritability of type-A trichome density was variable (18 to 32\%) (Mehlenbacher et al. 1984). Genes generally associated with trichomes have been linked to resistance in a hybrid population (Yencho et al. 1996). On the other hand, a QTL, not associated with trichomes was also strongly related to resistance against adult $\mathrm{CPB}$ (Yencho et al. 1996).

Parental lines derived from $S$. berthaultii after six back crosses have been released from Cornell University (NYL 235-4, Q174-2, and NYL 123) (Plaisted et al. 1992; De Souza et al. 2006; Malakar-Kuenen and Tingey 2006). Furthermore, hybrids derived from S. tarijense (PI414150) have been produced and evaluated at the Potato Research Centre, Fredericton, Canada (Pelletier, unpublished data).

\section{S. chacoense}

Solanum chacoense is the wild Solanum species that has received most attention for potato resistance to the $\mathrm{CPB}$ after $S$. berthaultii. The resistance to the CPB of $S$. chacoense is based on the presence of leptine I and II which are acetylated analogs of chaconine and solanine respectively and are produced only in the foliage (Sinden et al. 1991). Field and laboratory comparisons between clones from the same population expressing different level of leptines demonstrated that adult abundance, adult feeding, larval development rate, and larval survival were lower on clones with high levels of leptines (Sinden et al. 1986, 1988; Yencho et al. 2000) likely because of their strong feeding deterrence.

Somatic fusion is a necessary step for the introgression of $S$. chacoense with crop potato and leads to hybrids that are generally less resistant to adult CPB than the parents, but more resistant to larvae (Jansky et al. 1999). Early on, breeders experienced difficulties in maintaining a high level of resistance from $S$. chacoense in populations without sacrificing tuber quality (Torka 1950). The level of leptines remained high when a population of $S$. chacoense $\times S$. tuberosum hybrids were backcrossed with $S$. chacoense but decreased when $S$. tuberosum was used (Sanford et al. 1998). Two loci, involved in the synthesis of leptines have been identified. These segregate as two complementary epistatic genes, and allow the synthesis of leptinidine and acetyl-leptinidine, respectively (Sagredo et al. 2006). Other factors are likely necessary for the production of leptines in quantities sufficient to be an effective defense against the CPB (Sagredo et al. 2006).

Parental lines (including ND2858-1 and ND5873-16) issued from $S$. chacoense produced at the North Dakota State University have been used in breeding programs (Lorenzen and Balbyshev 1997; de Souza et al. 2006; Thompson et al. 2008). The clone, ND2858-1, derived from $S$. chacoense produces leptine I and II but at concentrations that do not explain the high level of resistance observed on this clone (Lorenzen et al. 2001). Irradiance and temperature influence the production of glycoalkaloid compounds including leptine I and II and might explain discrepancies with the identification of resistance factors (Lafta and Lorenzen 2000).

\section{S. pinnatisectum}

Very little is known about the mode of resistance to the CPB in S. pinnatisectum. The concentration of the glycoalkaloid tomatine might be responsible for part of the resistance of S. pinnatisectum (Sinden et al. 1991). However, using $S$. pinnatisectum as a scion, but not as rootstock, in a graft with potato foliage increased protection of the potato foliage indicating that the active factor was likely produced and translocated from the foliage (Pelletier and Clark 2004).

The genetics of resistance to the CPB in $S$. pinnatisectum was studied using a resistant $2 \mathrm{n}$ hybrid population with $S$. cardiophyllum (Chen et al. 2004) and revealed that only two genes are responsible for resistance in $S$. pinnatisectum (Nandy et al. 2008). Interspecific somatic hybrids between $S$. tuberosum and $S$. pinnatisectum were regenerated following electrofusion of mesophyll protoplasts (Thieme et al. 1997; Chen et al. 2008) and some of that material has been developed to the $\mathrm{BC}_{4}$ stage ( $\mathrm{R}$. Thieme, pers. comm.).

\section{S. tarnii}

Foliar consumption and survival of larvae was greatly reduced when beetles were maintained on foliage of $S$. tarnii (Sikinyi et al. 1997), but the exact factors involved are not yet known. Somatic fusion was used to produce hybrids between $S$. tarnii and $S$. tuberosum; that material was later back-crossed with $S$. tuberosum (Thieme et al. 2008) and is currently at the $\mathrm{BC}_{3}$ stage (R. Thieme, pers. comm.).

\section{S. polyadenium}

Four-lobed glandular hairs on the leaves and stems of the potato species $S$. polyadenium provide resistance to larvae of the CPB by producing a sticky material that traps larvae or encases their appendages; Larvae with encased feet fall from the plants to die (Gibson 1976b). However, using $S$. polyadenium as a scion, but not as rootstock, in a graft with potato foliage protected the potato foliage indicating that the active factor is also likely produced and translocated from the foliage (Pelletier and Clark 2004). Somatic fusion has been used to produce hybrids between $S$. polyadenium and S. tuberosum (Dr. John P. Helgeson, USDA/ARS, Department of Plant Pathology, University of Wisconsin, Madison, WI, pers. comm.); after a few back-crosses with $S$ tuberosum, the fertility of the cross was lost (Dr. H. De Jong, Potato Research Centre, AAFC, Fredericton, Canada, pers. comm.).

\section{S. neocardenasii}

$S$. neocardenasii foliage is densely covered with sticky trichomes; however, resistance to the CPB found in $S$. neocardenasii has been partly attributed to glycoalkaloids [tomatine and solanocardenine (Sinden et al. 1991) and/or solanocardinol (Osman et al. 1991)], whereas the removal of the trichomes did not affect the performance of either larvae or adult CPB (Dimock et al. 1986). 
Table 2 Mean ( \pm SEM) and coefficient of variation (c.v.) of potato, $S$. tuberosum, foliage consumption during a period of 24 h by male or female adult CPB of different ages. The optimal number of samples $(\mathrm{N})$ was calculated based on $\alpha=0.05$ (Sokal and Rohlf 1995).

\begin{tabular}{|c|c|c|c|c|c|c|c|c|c|}
\hline \multirow[t]{2}{*}{ Age } & \multicolumn{2}{|c|}{ Males } & \multicolumn{2}{|c|}{ Females } & \multicolumn{2}{|c|}{ Both Sexes } & \multicolumn{3}{|c|}{ Optimal N } \\
\hline & Mean \pm SEM & c.v. & Mean \pm SEM & c.v. & Mean \pm SEM & c.v. & $\hat{\sigma}$ & $q$ & Both \\
\hline 3 days & $9.35 \pm 0.31$ & 0.23 & $10.61 \pm 0.36$ & 0.25 & $10.05 \pm 0.25$ & 0.25 & 19 & 27 & 25 \\
\hline 5 days & $6.61 \pm 0.28$ & 0.28 & $9.52 \pm 0.32$ & 0.25 & $8.22 \pm 0.26$ & 0.32 & 34 & 24 & 33 \\
\hline 10 days & $6.17 \pm 0.25$ & 0.26 & $10.69 \pm 0.50$ & 0.34 & $8.66 \pm 0.37$ & 0.42 & 17 & 49 & 62 \\
\hline 17 days & $3.97 \pm 0.24$ & 0.39 & $6.83 \pm 0.50$ & 0.54 & $5.59 \pm 0.33$ & 0.58 & 24 & 78 & 76 \\
\hline
\end{tabular}

\section{Evaluation (screening) of resistance}

Breeding programs aiming to develop potato varieties resistant to insects produce thousands of seedlings for each cross a result of the complex genetics of resistance traits and of the genetics of potato. All those seedlings have to be evaluated for resistance to the target insect pest in order to select the best parents for the next generation. Similarly, hundreds of accessions of wild Solanum species have to be tested in order to find the best sources of resistance. These activities require the use of an efficient and reliable screening method. Early in the breeding process, the amount of plant material available for testing is very limited. The initial evaluation is often performed with one or a few plants from each genotype available. Two approaches have been used, field- and laboratory-based bioassays.

\section{Field tests}

Planting the potato plant in the field, exposed to natural populations of the CPB is the simplest way of evaluating resistance (Torka 1950). This method is limited by the availability of material from each accession or genotype to be evaluated (Sinden et al. 1988). Greenhouse grown tubers are sometimes very small and do not survive well in the field. Plants can be produced from cuttings in the greenhouse but this requires extensive labour to produce and transplant the material in the field. Plants from either production technique are frail, susceptible to lack of water, and susceptible to wind damage for the first few weeks as they establish.

Another disadvantage stems from the biology of the CPB. Because the plant material is usually difficult to produce, there are often few replications. As the CPB tends to aggregate at the border of fields or forests to overwinter, colonization of the test plots is often uneven and leads to variability in defoliation and in the distribution of larvae (Torka 1950; Sinden et al. 1988). Plastic lined trenches (Boiteau et al. 1994) deployed around the field test prevent colonization by walking resulting in a more even distribution of the adults (Pelletier and Tai 2001; Pelletier et al. 2001, 2007). This method will only work if beetles have not overwintered in the field and should be done in a field that was not planted with potato the previous year. Cultivated potato plants, the controls, can be distributed randomly or systematically in the plot to assess the distribution and relative abundances of the beetles.

Field plots are usually replicated and designed as randomized complete blocks (Carter 1987; Bamberg et al. 1996; Yencho et al. 2000; Pelletier and Tai 2001; Pelletier et al. 2001, 2007). Defoliation, expressed as a percentage, or following an index, is usually used as a resistance estimate and evaluated at the end of the larval stage during the first or second generation of the insect. The population of the insect can also be measured throughout the growing season.

\section{Data analysis}

The analysis of field evaluations of resistance that includes variables related to population development on the plants is difficult because of the relatively large number of variables that must be considered. Some authors have used multivariate analytical approaches, conducting factorial analyses to simplify the data set and make the resulting factors inde- pendent (Carter 1987; Pelletier et al. 2001, 2007) since population parameters (such as numbers of adults, eggs and larvae) are often correlated (Bamberg et al. 1996). This approach results in factors having significant biological meaning that could also be related to antibiotic and antixenotic characteristics of the plant.

\section{Lab feeding tests}

Laboratory tests can also be used to screen resistant populations. Such an approach allows the use of greenhouse materials, often produced from true seed, when growing that material is not possible in the field. One of the limitations of laboratory tests is the relatively high cost of producing the CPB indoor. Laboratory tests have also been used to test plant materials growing in the field using field caught insects. Both situations require limiting the test to one life stage of the CPB. Since adults and first instars make the decision to accept or reject the plant as a host then these are generally used during tests.

Screening tests with adults are usually limited to the evaluation of the quantity of foliage consumed in a period of time varying from 4 to 24 hours. Foliage consumption will vary with age and sex (Cantelo et al. 1987) of adult CPB (Table 2) and between overwintered and emerging adults (Pelletier and Smilowitz 1990). If one assumes that an optimal screening test should minimize variability in consumption of potato foliage, then at least 17 young (10days old) males should be used (Table 2). This would require a minimum (likely twice that value) of around 125 $\mathrm{cm}^{2}$ of foliage, the equivalent of 10 to 15 terminal leaflets from young fully developed leaves, which is a lot to harvest from a single greenhouse grown plant. This amount of foliage could be more easily attained from plants grown from tubers in the field but requires an extra year to produce the tubers. The influence of test duration on results has also been studied (Nandy et al. 2008). It was concluded that 8 hours was optimal because it produces a clearer genetic model of the plant resistance traits. However, they also identify the genetic model of the plant resistance trait based on the 8 hours test (other test durations leading to different genetic models) creating a circular argument. The repeatability of adult screening tests ( 2.5 hour tests) has also been evaluated by running tests twice (the second time after a 24 hour interval) with the same beetles. The relation between consumption of potato and $S$. berthaultii foliage during the two bioassays was poor, with coefficients of determination $\left(\mathrm{r}^{2}\right)$ varying from 0.16 to 0.52 , and was generally lower with females (Pelletier and Smilowitz 1990).

First instar larvae have been used in screening tests by several teams (Torka 1950; Yencho et al. 2000) and are more sensitive than tests using adults or larger larvae (Cantelo et al. 1987). First instars are easier to produce in the laboratory in large numbers; however, there are special requirements to insure that all the individuals are synchronized for development. This is especially important for bioassays of short duration where development is measured. Larvae from the same egg clutch emerge over a period of one or two hours. They first need to feed on the chorions of the eggs before they move to the plant foliage. During that time, the head capsule becomes completely schlerotized and goes from yellow through grey to black. At any given time within a few hours from the first larvae emerging, larvae with different head capsule colours can be seen in a single 
Table 3 Problematic gelechiids, indicating principal life-history and distribution aspects that determine their interactions with potato crops.

\begin{tabular}{lll}
\hline Site of egg laying & Feeding preferences & Main damage
\end{tabular}

Potato tuber moth [Phthorimaea operculella (Zeller)]

On dead potato leaves and in the soil close to host plant in the field; On tubers in storage (Traynier 1975; Das et al. 1993a, 1993b)

Often greater fitness on potato tubers compared to foliage, will also feed on tomato, eggplant and other Solanaceous crops (Traynier 1975; Raman and Palacios 1982)

Guatemalan tuber moth [Tecia solanivora (Povolny)] In soil at the base of the stem of flowering potato plants and on exposed tubers (Karlsson et al. 2009) Andean tuber moth [Symmetrischema tangolias (Gyen)]

On the stem of potatoes (Palacios et al. 1999)

Potato tubers (Dangles et al. 2009)

Potato stems, leaves, and tubers (Palacios et al. 1999; Dangles et al. 2009)

Tomato leaf miner [Tuta absoluta (Meyrick)]

On above-ground foliage (Pereyra and Sanchez 2006)
Tomato preferred over potato, not known to feed on tubers, feeds on a variety of other Solanaceous crops and wild plants (Pereyra and Sanchez 2006)
Damage to shallow and exposed tubers particularly in irrigated fields of warm regions; Severe damage to stored potatoes in cooler Andean regions (Shelton and Wyman 1979; Sileshi and Teriessa 2001; Dangles et al. 2009)

Damage to tubers in fields and stores (Dangles et al. 2009)

Damage to foliage, particularly severe in stems, and damage to tubers in fields and stores (Palacios et al. 1999; Dangles et al. 2009)

Mines leaves, fruits, flowers, buds, and stems (Pereyra and Sanchez 2006) egg clutch. Synchronization of the age of the larvae can be achieved by using "black head" larvae from an egg clutch that has been observed on a regular basis (every 30 minutes). A group of 10 first instar larvae can be used with around $5 \mathrm{~cm}^{2}$ of foliage for a test of 48 hours and only a few replicates is required (Cantelo et al. 1987) making it possible to evaluate resistance from a single plant grown in the greenhouse. First instar larvae can only be used in nochoice type bioassays. They are very reluctant to move from a leaflet or a disk, and if offered the choice of two acceptable leaflets or disks, $75 \%$ of the larvae will remain on the first plant material encountered over a period of 4 hours (Pelletier, unpublished data).

Investigating chemical defenses by isolating compounds and testing their effects on pests with in vitro bioassays can be inefficient and sometimes ineffective. Assays for chemical composition differences among plants segregating for resistance, an often overlooked alternative, can be more efficient and is sometimes the only effective strategy for identifying defense compounds (Sinden et al. 1988).

\section{POTATO RESISTANCE TO GELECHIID MOTHS}

Throughout the world, crop potatoes are attacked by the larvae of a diverse assemblage of lepidopteran species. These species occur across a variety of feeding guilds that includes leaf chewers [cutworms, Peridroma saucia Hübner, loopers, Trichoplusia ni (Hübner) and armyworms Pseudaletia spp.], stem-borers [European corn borer, Ostrinia nubilalis (Hübner), potato stem borer, Hydraecia micacea (Esper)] and leaf miners (tuber moths, see below) (Deedat et al. 1983; Kennedy 1983; Landolt 2001; Zeims et al. 2008; Dangles et al. 2009). Damage by these insects can sometimes increase the incidence of potato pathogens, e.g., corn-borers can increase the incidence of aerial stem rot caused by Erwinia carotovora (Jones) (Kennedy 1983) and moth damage to tubers increases fungal-related tuber-rot (Shelton and Wyman 1979; Sileshi and Teriessa 2001). Overall however, above-ground feeding by lepidopteran larvae rarely causes economic losses as many modern varieties of crop potato appear to have generally high tolerance to above-ground damage (Kennedy 1983; Nault et al. 2001; Zeims et al. 2008).

In contrast to the generally low levels of damage caused by leaf chewers and stem borers, considerable damage can sometimes result from attack by tuber feeding lepidopteran larvae, particularly among stored potatoes in tropical and sub-tropical regions. Among the most damaging tuber feeders are members of the family Gelechiidae, many of which co-occur in Andean potato producing regions (Table 3). Among these, Tecia solanivora (Povolny) feeds exclusively on potato tubers (Dangles et al. 2009), whereas Symmetris- chema tangolias Gyen and Phthorimaea operculella Zeller feed on both the foliage and tubers of potatoes and related plants (Palacios et al. 1999; Horgan et al. 2007b). A further species, Tuta absoluta (Povolny), occasionally feeds on foliage of crop potatoes but not on tubers (Campos 1976), and is primarily a problem in greenhouse tomatoes (Ecole et al. 2001; Leite et al. 2001; Pereyra and Sanchez 2006). Tuber moths will lay eggs directly on exposed tubers in the field (Sileshi and Teriessa 2001) or in rustic potato stores (Das et al. 1993a, 1993b); however, it is not well understood how populations of $S$. tangolias and $P$. operculella on foliage in the field affect subsequent damage to tubers. The occurrence of parasitic Copidosoma koehleri Blanchard among tuber moths collected from field infested tubers at Huancayo, Peru, suggest that mining larvae can move directly from foliage to tubers as the potato plants mature and tuberize (F. Horgan, pers. obs.). Moth populations can also build up on foliage, sometimes having developed from infested seed potatoes, and later, at the time of harvest, the newly emerged adults lay eggs on exposed or heaped tubers in the field (Kroschel and Koch 1994).

Recent studies have shown potential partitioning among the tuber moth species complex according to physiological responses to ambient temperatures at different altitudes (Dangles et al. 2008). In general, S. tangolias occurs at high altitudes $(>3000 \mathrm{~m}$ a.s.l.), $T$. solanivora occurs at lower altitudes $(<2700 \mathrm{~m}$ a.s.1.) and all three species can occur at mid-elevations (Dangles et al. 2008, 2009). The occurrence of two or more species together can result in greater levels of damage than a single species infestation, presumably because of feeding complementarities among the species (Dangles et al. 2009). Phthorimaea operculella is common at lower altitudes in regions without $T$. solanivora, and is often highly abundant in coastal regions (i.e., Peru, Campos 1976; Raman 1988). In Peru, it is likely that P. operculella infestations of potato stores at altitudes above $3000 \mathrm{~m}$ a.s.l. in inter-Andean valleys are due to repeated re-infestations from coastal regions and mid-altitudes during potato transport and by product movement between rustic stores (A.R. Salas and J. Alcazar, Centro Internacional de la Papa, Peru, pers. comm.).

\section{Foliage resistance}

Despite gelechiid larvae causing most damage to tubers, and often severe damage in potato storage facilities, the mechanisms of resistance in potato foliage are considerably better understood than resistance mechanisms in tuber (Gurr 1995; Musmeci et al. 1997; Malakar and Tingey 1999, 2000). Furthermore, good progress has been made in breeding for resistance to above-ground damage through introgression with trichome-bearing wild potato species (Plais- 
Table 4 Foliage resistance sources with associated fitness responses in target insects and proposed mechanisms of resistance.

\begin{tabular}{|c|c|c|}
\hline Insect Responses & Mechanism & Reference \\
\hline \multicolumn{3}{|l|}{ P. operculella } \\
\hline \multicolumn{3}{|l|}{ Nine Australian (Queensland) varieties } \\
\hline Fewer eggs laid & $\begin{array}{l}\text { Chemical (volatile and non-volatile) and mechanical cues } \\
\text { determine oviposition on different varieties, trichome } \\
\text { densities also affected oviposition, but effects were not } \\
\text { consistent. }\end{array}$ & Valencia 1984 \\
\hline \multicolumn{3}{|l|}{ Potato 'tarago', S. polytrichon, S. chacoense, S. pinnatisectum } \\
\hline Sources affected the numbers of eggs per leaf & $\begin{array}{l}\text { Leaf hairs on } S \text {. polytrichon and potato stimulate } \\
\text { oviposition. Reasons for low egg numbers on } S \text {. chacoense } \\
\text { and } S \text {. pinnatisectum are not known. }\end{array}$ & Gurr 1995 \\
\hline \multicolumn{3}{|l|}{ Many Indian commercial varieties and hybrids (19 varieties) } \\
\hline Sources affected the numbers of mines per leaf. & Not determined & Parihar and Chandla 1995 \\
\hline \multicolumn{3}{|c|}{$S$. berthaultii (4 accessions), $S$. pinnatisectum (2 accessions), $S$. sparsipilum (3 accessions), $S$. tuberosum $\times S$. berthaultii hybrids $(4$ accessions) } \\
\hline $\begin{array}{l}\text { Species effects on the numbers (and proportion of total } \\
\text { eggs) of eggs on leaves, and on total numbers of eggs laid. } \\
\text { Effects on successful establishment of neonates, larval } \\
\text { duration, larval survival, pupal weight, and fecundity }\end{array}$ & $\begin{array}{l}\text { High activity of polyphenol oxidase in the exudate } S \text {. } \\
\text { tuberosum } \times S \text {. berthaultii hybrids, and wild species with } \\
\text { glandular trichome A reduced larval growth. Type-A } \\
\text { trichomes also reduced fecundity. High levels of trichome } \\
\text { B repulsed oviposition, but without trichome B, leaf } \\
\text { pubescence stimulated oviposition. Significant antixenosis } \\
\text { of larvae was related to type A and B-trichomes. }\end{array}$ & Musmeci et al. 1997 \\
\hline
\end{tabular}

S. berthaultii, S. commersonii, S. pinnatisectum, S. sparsipilum (3 accessions), S. spegazzini, S. sucrense, S. tarijense (2 accessions), S. tuberosum $\times$ $S$. berthaultii hybrids (2 accessions)

Lower number of mines compared to cultivated potatoes. Not determined

S. berthaultii (2 accessions); Ber331 (trichome A\&B), Ber334 (trichome A only)

Lower proportion of total eggs on leaves and total eggs Synergy between type A and type B glandular trichomes

laid, lower neonate establishment, longer larval duration proposed as responsible for reducing fitness parameters. and lower pupal weight. Overall less damage to leaves
Arnoné et al. 1998

Malakar and Tingey 1999 , 2000

Gurr and McGrath 2002

Rêgo Lopes and Vendramim 2002

Horgan et al. 2007, 2009a $2009 \mathrm{~b}$

acting to reduce egg laying. Leaf hairs increased oviposition; Leaf pubescence was positively related to neonate establishment

Fitness reductions related to hexane leaf extracts.

Ecole et al. 2001 periods, lower hatchability of eggs, longer larval and pupal development times, lower survival and pupal weight, no effect on sex ratios, and overall fewer mines on the leaves.

L. hirsutum f. glabratum (acc. PI 134417)

Longer larval and pupal development times and lower survival and pupal weights, increased numbers of

deformed pupae, no effect on sex ratios, and overall fewer

Higher levels of tridecan-2-one and higher densities of glandular trichomes were associated with reduced moth fitness.

Leite et al. 2001 mines on the leaves.

ted et al. 1992; Malakar and Tingey 1999). However, in spite of the research attention, some simple behavioural and life-history aspects of tuber moths, including aspects of host location and egg-laying by adults, and host finding and penetration by neonate larvae, are still poorly understood; however, these behaviours and the environmental cues through which they are determined, are of key importance to the eventual outcome of moth attack, and to the meaningfulness and interpretation of screening and experimental studies.

Adult female tuber moths are attracted to potato plants largely through chemical stimuli (Table 4). Using electroantennogram studies, Das et al. (2007) have shown that certain fatty acid derivatives of green leaf volatiles elicit a significantly greater response in female $P$. operculella than in males, suggesting a role for these compounds in host finding for oviposition. Antennae from females further responded to a wide range of compounds that included monoterpenes, sesquiterpenes, and aromatics (Das et al. 2007) sug- gesting that complex blends of chemical compounds in the plant volatiles are responsible for host choice. Similarly, electroantennogram studies on female $T$. solanivora indicate responses to several sesquiterpenes and monoterpenes that are emitted only from foliage (and not from tubers, where the moth larvae feed) and to methyl phenylacetate that is released by flowering potato plants. Methyl phenylacetate is also present in the headspace of potato tubers (Karlsson et al. 2009). Which chemical cues determine attraction and oviposition responses have not been separated in these studies; however, choice studies by Valencia (1984) suggest that the egg-laying response is affected by combined chemical and mechanical cues: Discrimination coefficients for different concentrations of Soxhlet leaf extracts indicated repellant effects at high concentrations and attraction at lower concentrations and the non-volatile chemicals $\alpha$-solanine, zeatin riboside, $\alpha$-chaconine and chlorogenic acid were oviposition localizers compared to an ethanol (solvent) control; however, overall, more eggs were laid in 
containers treated with tomatine and glutamic acid; all volatile chemicals (trans-2-hexen-1-ol, 1-hexanol, cis-3-hexen1-ol, trans-2-hexenal, linalool) tested in the study had repellant effects. It is likely that whichever cues are involved in stimulating oviposition will also indicate the physiological state (herbivore or disease-stressed) and phenological stage of the host plant allowing females to determine the most suitable hosts for developing larvae. However, prior experience with a host plant [i.e., the host plant type (species or variety) on which the adult developed] may also interact with volatile cues to determine ultimate host acceptance and preferences (Landolt 2001).

The site of egg-laying varies between gelechiid species (Table 3) and, at least in $P$. operculella, is influenced by the host plant species (Varela and Barneys 1988). Palacios et al. (1998) indicate that the eggs of $S$. tangolias are predominately laid directly on the host plant, generally in an axilla in the mid-foliage region of the plant; however, after hatch, the site of larval entry into the stems is affected by plant phenology. Phthorimaea operculella appears to alter its site of oviposition according to chemical and mechanical cues from the host plant: In a study by Varela and Bernays (1988), eggs were laid predominantly on the foliage of potato plants but on the soil near datura, tobacco and tomato (all plants were pre-flowering). In contrast, Traynier (1975) found $P$. operculella eggs in the soil near potato and tobacco plants, but not near tomato. Eggs were mainly at the base of the plants, but small numbers occurred up to $2 \mathrm{~m}$ from the test plots. Optimum oviposition substrates for $P$. operculella include rough surfaces (with surface depressions large enough to accommodate the eggs), but hairy surfaces also stimulate oviposition (Traynier 1975; Fenemore 1978). In comparative studies with foliage from a range of potential host plants, leaf hairs have been associated with increased egg-laying by $P$. operculella directly on the leaf surface (Gurr 1995; Horgan et al. 2007a), whereas glandular trichomes reduced the proportion of eggs laid directly on the plants (Musmeci et al. 1997; Malakar and Tingey 1999, 2000; Gurr and McGrath 2002; Horgan et al. 2007a). Similarly, unidentified compounds in hexane leaf extracts of Lycopersicon hirsulutum f. typicum (LA 1777), and associated glandular trichomes, appear to deter egg-laying by $T$. absoluta, a species which does not lay eggs in the soil (Ecole et al. 2001). Glandular trichomes are likely to be an effective defense against those gelechiid species that lay their eggs on foliage (i.e., S. tangolias and T. absoluta) as well as other lepidopteran pests. For example, in field and greenhouse choice experiments, European corn-borer laid fewer eggs and caused less damage on $S$. tuberosum $\times S$. berthaultii hybrids NYL 235-4 and K411-2 that were originally bred for resistance to the CPB compared to the popular varieties Atlantic, Superior, Norland and Kennebec (Hanzlik et al. 1997), presumably because of glandular trichomes on the hybrids.

Because $P$. operculella (and possibly $S$. tangolias also) varies its site of egg-laying according to host plant identity, then glandular trichomes and other leaf deterrents may serve only to redirect egg-laying rather than reduce it in these species. To our knowledge, no study has adequately addressed this issue; Nevertheless, glandular trichomes derived from $S$. berthaultii bestow resistance against a wide range of herbivores (Neal et al. 1990; Hanzlik et al. 1997; Malakar and Tingey 1999) and genetic markers associated with trichome defenses are available that will increase the efficiency of potato breeding programs aimed at increasing herbivore resistance (Yencho et al. 1996). However, breeding for resistance based on glandular trichomes has associated caveats: There may be possible trade-offs between foliage and tuber resistance, such that breeding for high foliage resistance compromises resistance levels in tubers (Horgan et al. 2009b). Furthermore, glandular trichomes can inadvertently increase the susceptibility of potato plants to tuber moths in the field by decreasing the effectiveness of predators and parasitoids (Baggen and Gurr 1995; Gooderham et al. 1998; Mulata et al. 2004), e.g., C. koehleri makes fewer visits and remains for less time on trichome-bearing foliage, resulting in lower levels of parasitism on $P$. operculella eggs; furthermore adult $C$. koehleri can become entrapped in glandular trichomes (Baggen and Gurr 1995). This creates an enemy free space for tuber moths that has been linked to the shift by $P$. operculella in host plant preferences from low-trichome density potatoes to hightrichome density tomatoes in some regions (Mulatu et al. 2002).

Leaf trichomes may reduce damage to potatoes even where eggs are laid in the soil, if the trichomes deter dispersing neonates. The distances that neonates can travel to find suitable penetration sites are unknown. Neonates of $P$. operculella undertake exploratory walks following egg hatch that can continue at least up to two hours (F. Horgan, pers. obs.). Furthermore, neonates travel as much as $30 \mathrm{~cm}$ per minute over non-host plants (Varela and Bernays 1988). Having located a suitable feeding site, the neonates then burrow into the foliage and, depending on the nature of the leaf surface, may construct a protective silk tent (Horgan et al. 2007a). Neonates bite and taste the plant surface prior to host-plant penetration. Varela and Barneys (1988) have shown that dichloromethane and methanol extracts of leaf waxes increase the incidence of biting and that dichloromethane reduces the movement of neonate larvae, indicating a role for volatiles and other secondary chemicals in neonate establishment. Leaf pubescence also affects the behaviour of searching neonates (Malakar and Tingey 1999; Horgan et al. 2007a). Glandular type-A and type-B trichomes on Solanum berthaultii (Hawkes) and on Solanum tuberosum $\times S$. berthaultii hybrids have been shown to reduce successful neonate establishment (Musmeci et al. 1997); However, in a comparative study using a range of $S$. berthaultii accessions, Horgan et al. (2007a) found glandular trichomes to generally stimulate neonate establishment. Differences between the results of these studies may be due to the experimental protocols used: Musmeci et al. (1997) allowed neonates to colonize cut foliage in a choice experiment, whereas Horgan et al. (2007a) assumed that eggs are laid on the host plants, and placed neonates directly onto the leaf surfaces in non-choice tests. Trichomes, restricting larval movement [as in S. berthaultii (Malakar and Tingey 2000)] may have stimulated the neonates to penetrate leaf tissues more quickly when applied directly to the leaf surface. Because $P$. operculella lays eggs in both the soil and directly on the host plant, then, where sites of egg-laying are unknown, both protocols should be conducted. Furthermore, to increase the relevance of future such experiments for $P$. operculella and other moth species, the specific sites of egglaying should be assessed in parallel with neonate establishment experiments.

A number of studies have indicated decreased fitness of $P$. operculella and T. absoluta larvae following establishment on the foliage of resistant host plants compared to susceptible or favoured hosts (Musmeci et al. 1997; Malakar and Tingey 1999, 2000; Gurr and McGrath 2002): A variety of fitness parameters are detectably altered because of hostplant resistance factors: On resistant plants survival declines, larval development times increase, and larval and pupal weights and sizes decline (Table 4). The mechanisms behind these fitness declines are largely unknown and may include the effects of energy losses because of feeding difficulties associated with gumming of legs and mouthparts [Malakar and Tingey 2000; see also Neal et al. 1990 for the case of Myzus persicae (Sulzer)], the effects of toxic secondary chemicals, and/or the effects of poor nutritive quality of the foliage. Changes in larval survival as plants age give some clues as to the causes of observed fitness declines. For example, older plants of L. hirsutum f. glabratum (acc. PI 134417) have higher larval mortality, longer larval periods, smaller mines and more females of $T$. absoluta than on susceptible tomatoes. Leite et al. (2001) suggest that this is due to increasing levels of tridecan-2-one as leaves age. Evidence for poor nutritive value of resistant foliage is also suggested from observations of longer pupal 
Table 5 Tuber resistance sources with associated fitness responses in P. operculella and proposed mechanisms of resistance.

\begin{tabular}{|c|c|c|}
\hline Insect response evaluated & Mechanisms & Reference \\
\hline \multicolumn{3}{|l|}{ New Zealand varieties } \\
\hline Damage to tubers & Not determined & Fenemore 1980 \\
\hline \multicolumn{3}{|c|}{ Range of wild species and cultivated landraces (identities not indicated) } \\
\hline Damage to tubers & Not determined & Raman and Palacios 1982 \\
\hline \multicolumn{3}{|c|}{ New Zealand commercial varieties and true potato seed, some wild species (not listed) } \\
\hline Number of mines, number of tubers damaged & Not determined & Nabi 1984 \\
\hline \multicolumn{3}{|l|}{ Four commercial varieties grown in Kenya } \\
\hline Larval survival, tunnel form, number of tubers damaged & Not determined & Ojero and Mueke 1985 \\
\hline \multicolumn{3}{|c|}{ Wild species, hybrids, and traditional varieties over 5 years in Colombia (identities not listed) } \\
\hline Larval survival, damage & Not determined & Estrada and Valencia 1988 \\
\hline \multicolumn{3}{|l|}{ Twenty one commercial varieties } \\
\hline Number of mines, number of tubers damaged & Eye number related to vulnerability & Das et al. 1993a \\
\hline \multicolumn{3}{|l|}{ Twenty three varieties and genotypes } \\
\hline $\begin{array}{l}\text { Larval and pupal development time, larval survival, number of } \\
\text { mines, pupal and adult weights, oviposition, population growth } \\
\text { rate }\end{array}$ & $\begin{array}{l}\text { No effect of glycoalkaloids, soluble proteins and dietary } \\
\text { fiber on moth population growth, but total protein } \\
\text { content was positively- and digestible carbohydrates } \\
\text { negatively related to moth population growth. }\end{array}$ & Das et al. $1993 \mathrm{~b}$ \\
\hline
\end{tabular}

S. berthaultii, $S$. commersonii, $S$. pinnatisectum, $S$. sparsipilum (3 accessions), $S$. spegazzini, $S$. sucrense, $S$. tarijense (2 accessions), $S$. tuberosum $\times$ S. berthaultii hybrids ( 2 accessions)

Larval development time, larval survival, number of mines, Not determined Arnoné et al. 1998 pupal weight

Four Australian commercial varieties

Neonate establishment, adult emergence, number of mines

Periderm afforded $50 \%$ of the protection; most tunnels were made near tuber eyes

Chromosome-doubled regenerates of various hybrid potatoes derived from wild potato relatives

Damage scores
S. tuberosum $\times S$. berthaultii hybrids, Brazilian commercial potato varieties and tomato

Larval and pupal survival and development times, pupal weight $\quad$ Not determined

Gurr and Symington 1998

Many commercial varieties and true potato seed

Number of mines, number of tubers damaged

Exposure of tubers (above the soil) was correlated with Sileshi and Teriessa 2001 damage levels.

S. tuberosum $\times S$. berthaultii hybrids

Eggs laid, larval establishment, larval survival, larval size, larval behaviour

Periderm thickness affected neonate penetration of the Malakar-Kuenen and Tingey tuber and oviposition. The periderm is thinner around the 2006 eye resulting in increased vulnerability of the eye to larval entry.

Various accessions of $S$. berthaultii ( 23 accessions) Establishment of neonates, larval and pupal development times, pupal weights

Tuber resistance is determined by i) a periderm barrier to Horgan et al. 2007b, 2009b neonate attack and ii) unfavourable nutritional/habitat conditions in the tuber cortex. As the tuber ages both resistance sources break down.

Various accessions of $S$. multiinteruptum (8 accessions), $S$. sparsipilum (8 accessions) and $S$. wittmackii (9 accessions) Establishment of neonates, larval and pupal development times, Resistance in S. multiinteruptum is mainly due to pupal weights periderm protection, whereas resistance in $S$. sparsipilum and $S$. wittmackii is mainly cortex based.

development times (suggesting carry-over effects of poor nutrition to the non-feeding pupal stage), whereas observations of lower pupal survival and higher proportions of deformed pupae (i.e., Ecole et al. 2001; Leite et al. 2001) suggest that some resistant foliage may also contain compounds that are toxic to developing larvae. Similarly, adult $P$. operculella reared on its preferred host (potato) had lower female egg loading values and lower lipid content, and had a resulting lower tendency to fly when compared to $P$. operculella reared on a non-preferred host (tomato) (Coll and Yuval 2004), suggesting that adults will more readily disperse away from poor quality hosts.

\section{Tuber resistance}

Damage to tubers by gelechiids is considerably more problematic than damage to above-ground foliage. Among poor rural communities in the Andes, where potatoes are stored in rustic storage facilities, losses can be up to $100 \%$ (Dangles et al. 2009). Under the relatively stable environments of storage facilities $S$. tangolias, $T$. solanivora and $P$. operculella can rapidly build up numbers (Das et al. 1993a, 1993b; Dangles et al. 2009). To compound the problem, often two or three of the species occur together (Dangles et al. 2009). As such, the principal gelechiid tuber moths are as much stored-product pests as they are field crop pests. Infestations of tubers in the field can also be considerable, especially where soil conditions or crop varieties lead to large numbers of exposed tubers (Sileshi and Teriessa 2001). Furthermore, for $S$. tangolias and P. operculella, survival and resulting pupal weights are generally higher on tubers than on foliage (F. Horgan pers. obs.); Rêgo Lopes and Vendramim (2001) also found higher survival of $P$. operculella on tubers than on foliage (but surviving larvae had longer development times and lower pupal weights on tubers) except on $S$. tuberosum $\times S$. berthaultii hybrids (NYL 235-4 and N 140-201) where larvae did poorly on tubers. Given that tuber moths are better adapted to living on tubers, and given the large number of published tuber screening studies (Fenemore 1980; Raman and Palacios 1982; Nabi 1984; Ojero and Muerke 1985; Estrada and Valencia 1988; Ortíz et al. 1990; Das et al. 1993b; Chandla 1995; Arnoné et al. 1998; Gurr and Symington 1998; Parihar and Watanabe et al. 1999; Rêgo Lopes and Vendramim 2001; Sileshi and Teriessa 2001; Horgan et al. 2007b, 2010) it is surprising that so little is known about mechanisms of tuber resistance to the moths (Table 5). Furthermore, there is little information on which to base hypotheses about tuber resistance, 
because, other than recording damage levels or herbivore survival, only a few studies have quantified moth fitness responses to resistant tubers (but see Arnoné et al. 1998; Malakar-Kuenen and Tingey 2006; Horgan et al. 2007b, 2010).

As with foliage, adult moths likely locate tubers based on complex chemical cues emitted from the host plants. These cues will indicate that the plant is at a suitable phenological stage for tuberization. Hence, T. solanivora adults are attracted to cues emitted from flowering plants (see above, Karlsson et al. 2009) and field observations indicate that $P$. operculella is attracted to flaccid plants and lays its eggs on dead leaves (Traynier 1975; Shelton and Wyman 1979). Karlsson et al. (2009) indicate, based on electroantennogram results, that volatile methyl phenylacetate may attract female $T$. solanivora directly to the tubers.

Once eggs hatch, either on foliage or in the soil (see above), the neonates seek out the developing tubers. In the field, the first line of defense against neonate penetration of tubers is tuber apparency: Increasing burial depths reduces damage by both P. operculella (Foot 1975) and S. tangolias (Palacios et al. 1999) because neonates fail to reach deeper tubers. Tuber dept is largely under genetic control (Sileshi and Teriessa 2001), but is seldom regarded in resistance studies. The spatial distribution of tubers in the soil beneath the plant may also influence herbivore attack (Winkler and Fischer 1999), but this has not been studied for potatoes.

On reaching tubers, either in the field or in storage, the next principal barrier to neonate penetration is the tuber periderm. The periderm consists of numerous layers of cork (Cutter 1992). The outer phellem layers contain wax and subarins that form an effective barrier to water. Periderm thickness and chemical composition vary according to potato species, variety, and the environmental conditions during tuber development (Cutter 1992; Tyner et al. 1997). The periderm can contribute from 0 to $100 \%$ of total resistance in wild potatoes (Horgan et al. 2007b, 2010), but, more typically is only a part of the tuber defense with the remainder related to cortex properties (Horgan et al. 2007b). Because the periderm is considerably thinner near the tuber eyes, most neonates enter tubers (both commercial varieties and wild potato species) through the eyes (Gurr and Symington 1998; Malakar-Kuenen and Tingey 2006; Horgan et al. 2007b). Tunneling through the periderm can reduce larval development times in $P$. operculella by up to one day on some accessions of Solanum sparsipilum (Bitter) Juz. et Buk. and Solanum wittmackii Bitter, suggesting that even when larvae successfully establish on tubers, penetration of the periderm may have an associated cost (Horgan et al. 2010).

Survival, larval and pupal development times, and pupal weights of $P$. operculella reared on tubers of $S$. berthaultii vary between accessions, which indicates that the cortex plays a significant role in tuber resistance based on its nutritive value for developing moths (Horgan et al. 2007b); Secondary chemicals, such as glycoalkaloids, appear to play little or no role in the resistance of commercial varieties (Das et al. 1993a) and occur at very low levels in $S$. berthaultii (Y Pelletier, unpublished data). However, tubers of $S$. wittmackii have strong antibiotic defenses, such that the establishment of neonates is often lower in tubers with perforated periderms compared to unperforated tubers (suggesting a repellent effect of the cortex and/or induced responses to perforation). Furthermore, larval mortality and tuber abandonment are high and pupal deformities are relatively common when larvae feed on $S$. wittmackii (Horgan et al. 2010). Chemical toxins in the cortex of $S$. wittmackii are therefore largely responsible for tuber resistance in this species (Horgan et al. 2010). It is unlikely that such a plant could be used in breeding programs to develop resistant tubers for human consumption.

Das et al. (1993a) found the tubers of some commercial varieties to become more susceptible to damage by $P$. operculella as the tubers aged. Similarly, as tubers of $S$. berthaultii, S. multiinteruptum and S. sparsipilum sprout, their resistance breaks down (Horgan et al. 2007b, 2010). This is partly due to a decrease in the protective value of the periderm; however, higher survival rates, shorter development times and heavier pupae suggest that, as the tubers sprout, their nutritional quality for developing larvae often increases (Horgan et al. 2007b, 2010). Developing tubers undergo a range of physiological changes, including the disappearance of protein crystals, decreases in saturated and unsaturated fatty acids, hydrolysis of starch, and increases in soluble carbohydrate levels (Cutter 1992; Coleman 2000) In contrast to the studies by Das et al. (1993a) and Horgan et al. (2007b, 2010), Malakar-Kuenen and Tingey (2006) found increased larval mortality on older tubers of Atlantic and old $S$. tuberosum $\times S$. berthaultii hybrid tubers when compared to newly harvested tubers. Difference between these studies may derive from the nature of aging and whether tubers were sprouting and flaccid or dried-out from cold storage. In S. wittmackii, older tubers also have lower resistance; however, on this species, other than increased establishment of neonates, $P$. operculella fitness does not increase with sprout development and larval mortality and abandonment of tubers remains high (Horgan et al. 2010). Lower resistance against tuber moths on sprouting tubers suggests that resistance is related to tuber dormancy (Horgan et al. 2007b, 2010). For example, the highly resistant species $S$. multiinteruptum and $S$. wittmackii occur at high altitudes in the Andes and have notably long dormancies (over seven months in some accessions). In general, wild potato species with relatively longer dormancies tend to be more resistant to tuber moths based on comparative screening of newly harvested tubers (F Horgan, unpublished data).

\section{POTATO RESISTANCE TO APHIDS}

Aphids (Hemiptera: Aphididae) are also considered among the most damaging insect pests on cultivated potato (van Emden et al. 1969; Radcliffe 1982). They decrease potato yield by consuming phloem sap and by transmitting viruses such as the persistent Potato Leaf Roll Virus and the nonpersistent Potato Virus Y (Radcliffe 1982). Myzus persicae (Green Peach Aphid) and Macrosiphum euphorbiae (Potato Aphid) (Thomas) are the most damaging species, although other species colonize potato crops (Blackman and Eastop 1994) among which Aphis nasturtii (Kaltenbach), Aulacorthum solani (Kaltenbach) and Rhopalosiphoninus latysiphon (Davidson) cause notable damage (Radcliffe 1982). Numerous other aphid species have been collected from potato field traps, but their ability to colonize potato is uncertain (Boiteau 1988; Difonzo et al. 1997; Bostan et al. 2006). A life-cycle that includes polyphenism (alternate production of alate and apterous morphs by the same genotype, which occurs during summer when aphids feed on potato crops), alternation of sexual and asexual reproduction (Miyasaki 1987; Dixon 1998), a tight relationship with the plant during the host selection process (Powell et al. 2006), and endosymbiosis with gut bacteria (Douglas 2003) are key characteristics that contribute to the status of aphids as global agricultural pests.

\section{Sources of resistance}

The levels of resistance to aphids have been assessed for a variety of potato cultivars (Adams 1946; Landis et al. 1972; Bintcliffe and Wratten 1982; Davis et al. 2007). The most recent and most thorough study has not detected any correlation between resistance levels and the abundance of two major aphid species, M. persicae and M. euphorbiae (Davis et al. 2007). The cultivar 'Russet Norkotah' was the most resistant to $M$. persicae and 'Aracy' the most resistant to $M$. euphorbiae. Despite an impact on aphid population growth sufficient to reduce the need for insecticide applications (Davis et al. 2007), resistance in cultivated potato depends more on plant physiology and growth habitat than on heritable traits (Radcliffe 1982). Inconsistencies in the results of field assessments between years corroborate this conclusion 
(Davis et al. 2007).

More than 50 years ago, researchers emphasized the need to improve potato germplasm by introgressing commercial varieties with wild Solanum species as sources of novel resistance (Adams 1946; Landis et al. 1972). A number of studies have evaluated resistance levels to M. persicae and M. euphorbiae of Solanum species (Radcliffe and Lauer 1968; Quisumbing et al. 1970; Radcliffe and Lauer 1970a, 1970b; Gibson 1971b; Radcliffe and Lauer 1971a, 1971b; Sams et al. 1976; Radcliffe et al. 1981; Flanders et al. 1992; Valkonen et al. 1992; Flanders et al. 1997, 1999). Resistance levels generally differ according to aphid species (Gibson 1971b; Radcliffe et al. 1981); However, studies have identified a range of potential sources of aphid resistance for potato including $S$. chomatophilum (Radcliffe and Lauer 1970a; Flanders et al. 1992, 1997; Le Roux et al. 2007; Pompon et al. 2010b), S. trifidum (Radcliffe et al. 1981; Flanders et al. 1992, 1997; Pelletier et al. 2010), S. stoloniferum (Radcliffe and Lauer 1970a, 1970b; Gibson 1971b; Radcliffe and Lauer 1971b; Radcliffe et al. 1981; Flanders et al. 1992; Le Roux et al. 2007), and S. hjertingii (Radcliffe and Lauer 1970a; Radcliffe et al. 1981; Flanders et al. 1992). Solanum etuberosum was found to be resistant to both aphids and viruses (Valkonen et al. 1992; Flanders et al. 1997; Novy et al. 2002). Solanum berthaultii, S. polyadenium and $S$. neocardenasii all bear glandular trichomes that have been associated with resistance against other potato herbivores as well (see above; Lapointe and Tingey 1986; Malakar and Tingey 2000; Novy et al. 2002; Alvarez et al. 2006). To our knowledge, the only commercial variety bred for aphid resistance, 'King Harry' (De Jong, W., pers. comm.), has been commercially available since 2004, and has trichome-mediated resistance inherited from $S$. berthaultii.

\section{Mechanisms of resistance}

The mechanisms of resistance based on insect responses can be classified as either antixenosis or antibiosis (Panda and Khush 1995). Antixenosis is based on plant factors that interfere with the behaviour of the insects such as the host selection process. Antibiosis mechanisms are caused by plant factors impairing insect physiology. Both types of mechanism are not mutually exclusive and can sometimes be triggered by the same compounds at different concentrations (Niemeyer et al. 1993).

Host-plant selection by aphids has been defined as a sequence of six behavioural stages guided by chemical and physical plant characteristics: i) pre-alighting behaviour; ii) initial plant contact and assessment of surface cues before probing; iii) probing the epidermis; iv) stylet pathway activity in the mesophyll; v) salivation; and finally vi) phloem acceptance and sustained ingestion (Powell et al. 2006). At each stage, the aphid can reject the plant or resume one of the previous behavioural stages. The pre-alighting stage appears to have little effect on host-plant selection, as aphids have little control over the direction of their flight (Dixon 1998). Before inserting the stylet (probing), aphids evaluate the suitability of the plant surface by antennating while walking on the leaf to detect odour and gustatory cues (Powell et al. 1995). Colour also stimulates probing behaviour (Pelletier 1990). Delay in stylet insertion suggests the presence of repellent plant factors in the superficial layers, as for $M$. persicae on $S$. polyadenium, S. berthaultii, S. tarijense, $S$. spegazzinii, $S$. circaeifolium subsp. capsicibaccatum, and $S$. stoloniferum (Alvarez et al. 2006; Pompon et al. 2010a). Trichomes are responsible for the resistance in $S$. polyadenium, $S$. berthaultii, and $S$. tarijense, whereas stylet derailments are also observed on $S$. stoloniferum and suggest the presence of plant factors impairing stylet penetration. Aphids insert their stylet into intercellular spaces in epidermal and mesophyll tissues, and puncture some cells to gain gustatory information along the pathway towards phloem bundles (Powell et al. 2006). Cell puncture frequency can be influenced by symplastic plant characteristics (Chen et al.
1997). A longer "pathway phase", as for $M$. persicae on $S$. chomatophilum (Le Roux et al. 2008; Pompon et al. 2010a), is thought to be caused by resistance factors detected in the mesophyll. An increase in the number of short probes $(<3$ min) is interpreted as unfavourable epidermis tissue because aphids cannot reach deeper tissue during that time (Powell et al. 2006). Salivation is the first behaviour performed after reaching phloem bundles and always occurs before phloem ingestion. Ejection of saliva prevents sieve element sealing (Tjallingii 2006), which is part of the plant wound response, by inhibiting the coagulation of bound p-proteins (forisome) (Tjallingii 2006). Although the mechanism is calciummediated, the release of saliva is triggered by a drop in phloem sap hydrostatic pressure (Tjallingii 2006). Failure to overcome the plant wound response may result in an extended salivation period and a shorter phloem sap ingestion duration (Tjallingii 2006), as observed for M. persicae on $S$. stoloniferum (Le Roux et al. 2008), and for M. euphorbiae on S. oplocense, S. stoloniferum (Pompon et al. 2010a) and S. trifidum (Le Roux et al. 2008). Salivation also increases when aphids face nutritionally unbalanced (Ponder et al. 2000) or toxic phloem sap (Ramirez and Niemeyer 1999), which is suggested to underlie $S$. pinnatisectum resistance to M. euphorbiae (Pompon et al. 2010a). Aphids eventually reach phloem sieve elements, where a sustained phloem sap consumption period ( $>10 \mathrm{~min}$ ) can be interpreted as plant acceptance (Tjallingii 1994). Nutritionally unbalanced or toxic phloem sap may also be responsible for difficulties in maintaining phloem sap ingestion, as suggested for $M$. persicae on S. multiinterruptum (Alvarez et al. 2006), and for $M$. euphorbiae on $S$. polyadenium and S. tarijense (Pompon et al. 2010a).

Aphids also consume xylem sap in order to regulate the gut content osmotic pressure (Pompon et al. 2010c; Pompon 2010). Although xylem sap consumption of M. euphorbiae increases on resistant accessions from $S$. chomatophilum, S. oplocense, and S. pinnatisectum (Le Roux et al. 2008; Pompon et al. 2010b), its role in host-plant selection is still under investigation.

Electric penetration graphs (EPG) have been used extensively in research on aphid-plant interactions and permit detailed monitoring of aphid host-plant selection behaviour (Tjallingii 1995). However, experimental stresses inherent to EPG manipulation, such as the application of a drop of conductive glue on the dorsum (Pelletier and Giguère 2009), can modify aphid behaviour (Prado and Tjallingii 1999). Ethological observations should complement EPG analyses to prevent misinterpretation of the resistance mechanisms (Prado and Tjallingii 1999; Pelletier and Giguère 2009). Behavioural datasets, such as EPG or ethological observation data, suffers from multicollinearity, which can be handled using multivariate analysis (Quinn and Keough 2002). Multivariate analyses select a subset of relevant variables (Caillaud et al. 1995; Sokal and Rohlf 1995), and treats multiple variables simultaneously, both of which reduce type I errors (excessive rejection of the null hypothesis) associated with numerous sequential univariate tests (Quinn and Keough 2002). Multivariate statistics have been successfully used in assessing resistance mechanisms (Caillaud et al. 1995; Pompon et al. 2010a).

Antibiosis mechanisms are usually indirectly inferred when there is no change in herbivore behaviour between the resistant plant and a susceptible standard (Alvarez et al. 2006; Le Roux et al. 2008). Solanum cardiophyllum and $S$. circaeifolium subsp. capsicibaccatum resistance to $M$. persicae, and $S$. chomatophilum resistance to $M$. euphorbiae have been attributed to antibiosis mechanisms (Alvarez et al. 2006; Le Roux et al. 2008; Pompon et al. 2010a). However, these types of indirect observations alone do not provide sufficient evidence for antibiosis since long term behavioural response and induced resistance may be overlooked during the period during which the behaviour is assessed.

Chemical or physical plant characteristics are ultimately responsible for insect resistance (Flanders et al. 1992). Glycolalkaloids are known to impact insect performance 
(Flanders et al. 1992), but total foliar quantity were not correlated with $M$. persicae infestations in potato cultivars, in $S$ tuberosum $\times$ wild Solanum hybrids, nor in wild Solanum species (Mndolwa et al. 1984) including S. berthaultii (Tingey and Sinden 1982). However, this does not exclude the role of specific alkaloids. No chemical or physical characteristics other that trichomes have been directly attributed to aphid resistance in tuber-bearing Solanum species.

Trichome-based resistance occurs in S. berthaultii (including S. tarijense), S. polyadenium, (Gibson 1971a, 1976), S. neocardenasii (Lapointe and Tingey 1986), and S. flavoviridens (Ochoa 1980). Observed levels of aphid resistance have been positively correlated with trichome densities (Tingey and Laubengayer 1981); however, resistance is significantly improved where two types of glandular trichome, type-A and type-B, are present (Tingey and Sinden 1982) (see above for the description of trichome types). Trichomemediated resistance to aphids involves several steps (Gregory et al. 1986): The insect lands upon the foliage and encounters the type-B trichome exudate, which forms an adhesive coating on the tarsi, and also elicits an antifeedant behaviour through its sesquiterpene content; The insect struggles during attempts to escape and breaks the type-A trichome heads; $\alpha$ - and/or $\beta$-polyphenol oxidases are released from the broken head of type-A trichomes and react with a phenolic substrate (chlorogenic acid) to initiate an enzymatic oxidative process leading to the formation of quinones. Eventually, the insect becomes immobilized, ceases feeding, and dies. E- $\beta$-farnesene, an aphid alarm pheromone, was proposed to worsen the behaviour disturbance (Gibson and Pickett 1983), but its major effect was later contested since high concentrations of E- $\beta$-farnesene were also found in susceptible $S$. tuberosum (Avé et al. 1987). However, the concentration and presence of particular compounds vary between species (Avé and Tingey 1986), accessions, and cultural conditions (Avé et al. 1987). Despite protecting against aphid damage and virus transmission, due to delayed aphid probing (Lapointe and Tingey 1984), trichome-based resistance has disadvantages. Trichomes are not present on buds and flowers, enabling aphids to colonize these plant parts (Ashouri et al. 2001). Under field conditions, depletion of type-A trichomes through ware, especially on the mature leaves that are preferred by $M$. persicae (Tingey et al. 1982), and dust on the exudates (Tingey and Sinden 1982) reduce the resistance level. Furthermore, the production of trichome B exudate is strongly associated with unfavorable agronomic traits in $S$. berthaultii $\times S$. tuberosum hybrids (Kalazich and Plaisted 1991).

\section{Evaluation of resistance}

Understanding the plant factors that influence resistance levels is helpful to guide the selection of resistant parents and develop effective screening protocols. Resistance levels vary among accessions of the same species (Radcliffe et al. 1981; Flanders et al. 1992). Flanders et al. (1997) have related aphid resistance to the geographical origin of wild Solanum accessions. High resistance to $M$. persicae was more prevalent than expected in accessions from Mexicosouthern United States, Peru, and a region extending from southern Bolivia to northern Argentina. High resistance to M. euphorbiae was more prevalent in accessions from Mexico, and west and east-central Peru. Because individuals within accessions are obtained by sexual reproduction then each individual plant is unique, which might explain why resistance levels can vary among plants from the same accession [Sams et al. 1976; Pompon et al. unpublished data; but see Bamberg et al. (2000)]. Resistance levels can also vary between different plant parts (Gibson 1971b; Valkonen et al. 1992; Ashouri et al. 2001; Le Roux et al. 2008; Pompon et al. 2010b). However, irrespective of intra-plant variation of resistance levels, $M$. persicae generally prefers senescing leaves (van Emden et al. 1969), whereas $M$. euphorbiae prefers flower buds and flowers (Gibson 1971b).

Aspects of aphid biology that promote variation in resistance levels need to be better understood. The occurrence of biotypes is promoted by the long asexual period of the aphid life cycle (van Emden et al. 1969; Dixon 1998). Each fundatrix hatching in the spring from the overwintered egg represents a different biotype, potentially having different fitness levels. The resistance levels of a given plant can vary depending on the aphid biotype studied (Gibson and Plumb 1977), e.g. different biotypes of M. euphorbiae perform differently on tomato plants carrying the $M i$ gene (Goggin et al. 2001). Nevertheless, the resistance of wild Solanum species to $M$. persicae was found to be stable in space and time (Radcliffe et al. 1974; Radcliffe et al. 1988). Endosymbiotic bacteria housed by aphids in specialized cells can influence host-plant range (Douglas 2003; Simon et al. 2003) and, as bacteria evolve faster than insects, genetic or epigenetic changes in the endosymbionts might accelerate aphid adaptation to resistant varieties.

\section{CONCLUSIONS AND FUTURE PROSPECTS}

The potential of wild potato species as sources of novel resistance to major potato insect pests has been demonstrated through a large number of screening studies conducted over the past 50 years. Furthermore, the successful introgression of wild species with cultivated potato has been achieved and produced some commercially available varieties with improved resistance against the $\mathrm{CPB}$, tuber moths, and aphids. Methods to achieve introgression and secure the transfer of genes and QTLs of interest have improved and will certainly accelerate the pace of cultivar development from wild and cultivated parents. Nevertheless, the availability of introgressed materials is still quite low and very few wild species have been used as resistance sources. Most of the available cultivated hybrids have been developed through introgression with $S$. berthaultii which bears glandular trichomes and for which the mode of action in resistance against the CPB, tuber moths, and aphids is relatively well understood.

Resistance from other wild potato species has been slower in coming. This may partly be due to difficulties in quantifying those elements (either secondary chemicals, volatiles or anatomical barriers to the insects) that determine resistance. Furthermore, direct links between resistance factors and QTLs or major resistance genes have been difficult to establish because of variable responses by target insects to the host materials and variable distributions and levels of the resistance factors in the host plants. Resistance can sometimes change with plant age (as discussed above with trichome defenses to aphids and tuber resistance to moths) and are often heavily influenced by environmental conditions. The identification of the compounds produced by the plant that bestow resistance needs to be improved. The task is likely to become easier with the development of new and advanced metabolomic tools. Along with the development of the genomic tools and the sequencing of the potato genome, breeding for insect resistance is likely to require less time and an increased number of wild parents can be used in breeding programs.

Screening studies have been useful in identifying promising species and accessions for attention in resistance breeding programs. However screening results are seldom published and in some cases, even when published, the identity of the source materials is omitted. Furthermore screening studies are notoriously variable, partly because of the lack of rigour among researchers in standardizing screening methodologies. Tests will often vary screening procedures, plant age, insect age, temperatures and/or the layout of the screening unit. Fine screening with parallel insect-behavioural observations can greatly improve the reliability of results. Although field studies provide realcondition estimation of the resistance level, laboratory assessment of the resistance mechanisms is required to obtain further information on the nature of the resistance. Correlation and associative type experiments can further improve our understanding of resistance mechanisms and 
improve reliability. Studies that record numerous plant anatomical and chemical parameters and/or insect behavioural and fitness responses end with complex data sets that can be managed and reduced using multivariate statistical techniques. Advances in statistical software and multivariate procedures have therefore become a useful tool in improving knowledge for breeding purposes. Furthermore, multivariate analyses permit researchers to take more holistic views of the interactions between the plants and insects of interest. Most of the studies that have been conducted to date on potato resistance to insects have followed reductionist experimental approaches and few have conducted manipulative experiments. Manipulative experiments, where factors are experimentally manipulated in order to confirm or reject a specific test result (i.e., removal of trichomes, piercing of periderm) are required to determine the processes behind resistance, since correlation and associationtype studies will always be subject to the problems of confusing cause and effect, even when multivariate statistics are applied. But, manipulative studies still tend to be reductionist by nature. The popularity of the EPG system has created an abundance of studies on aphid host-plant selection behaviours on resistant plants in many other aphid-plant systems. Since this technique can only address short-term selection behaviour differences between resistant and susceptible plants, it creates a bias towards antixenosis mechanisms. The reduction of research focus on plant-insect interactions to restricted events has been particularly problematic in research on tuber moths: surprisingly, the site of egg laying and the oviposition response of female moths to trichome-bearing plants is still poorly understood. It is unknown whether trichomes deter or simply redirect egg laying (to the soil).

In insects such as tuber moths, that attack both foliage and tubers, the complete life-cycles of the insects and the plants should be considered as trade-off in resistance can occur, or resistance sources can produce unpalatable or poisonous tubers, sometime only under certain environmental conditions. Holistic approaches to the deployment of resistant varieties once these are developed should also be considered. Trichome-bearing potatoes have been associated with increased mortality of natural enemies in the field and can produce preference shifts by pest insects in response to enemy-free space. This could affect the success of resistant varieties as part of integrated pest management strategies. Similar effects on other wild-introgressed potato varieties with distinct resistance mechanisms are perhaps unlikely; nevertheless, potential negative effects should be considered as in the case of all insect management technologies.

The prospects of using wild species in future potato breeding programs are good, especially with the development of new molecular and statistical techniques. We caution that experimental and screening procedures should take more holistic views of the plant-insect system to further improve the success of resistance development and the impact of varietal deployment. The range of wild species and novel resistance mechanisms that is available to breeding programs is large given the improved techniques for attaining introgression. Nevertheless, until now, progress has been limited mainly to introgression of a few trichomebearing species and particularly S. berthaultii. Many other wild potato species hold promise as novel sources of resistance, especially against foliage herbivores.

\section{REFERENCES}

Adams JB (1946) Aphid resistance in potatoes. American Potato Journal 23, 1 22

Alvarez AE, Tjallingii WF, Garzo E, Vleeshouwers V, Dicke M, Vosman B (2006) Location of resistance factors in the leaves of potato and wild tuberbearing Solanum species to the aphid Myzus persicae. Entomologia Experimentalis et Applicata 121, 145-157

Arnoné S, Musmeci S, Bacchetta L, Cordischi N, Pucci E, Cristofaro M, Sonnino A (1998) Research in Solanum spp. as sources of resistance to the potato tuber moth Phthorimaea operculella (Zeller). Potato Research 41, 3949
Ashouri A, Michaud D, Cloutier C (2001) Unexpected effects of different potato resistance factors to the Colorado potato beetle (Coleoptera: Chrysomelidae) on the potato aphid (Homoptera: Aphididae). Environmental Entomology 30, 524-532

Avé DA, Gregory P, Tingey WM (1987) Aphid repellent sesquiterpenes in glandular trichomes of Solanum berthaultii and S. tuberosum. Entomologia Experimentalis et Applicata 44, 131-138

Avé DA, Tingey WM (1986) Phenolic constituents of glandular trichomes on Solanum berthaultii and S. polyadenium. American Potato Journal 63, 473480

Baggen LR, Gurr GM (1995) Lethal effects of foliar pubescence of solanaceous plants on the biological control agent Copidosoma koehleri Blanchard (Hymenoptera: Encyrtidae). Plant Protection Quarterly 10, 116-118

Bamberg JB, Longtine CA, Radcliffe EB (1996) Fine screening Solanum (potato) germplasm accessions for resistance to Colorado potato beetle. American Potato Journal 73, 211-223

Bamberg JB, Singsit C, Del Rio AH, Radcliffe EB (2000) RAPD analysis of genetic diversity in Solanum populations to predict need for fine screening. American Journal of Potato Research 77, 275-278

Bintcliffe EJB, Wratten SD (1982) Antibiotic resistance in potato cultures to the aphid Myzus persicae. Annals of Applied Biology 100, 383-391

Blackman RL, Eastop VF (1994) Aphids on the World's Trees: An Identification and Information Guide, CAB Wallingford, UK, $476 \mathrm{pp}$

Boiteau GR, Singh RP, Pelletier Y (1988) The spread of PVY in New Brunswick potato fields: Timing and vectors. American Journal of Potato Research 65, 639-649

Boiteau G, Pelletier Y, Misener GC, Bernard G (1994) Development and evaluation of a plastic trench barrier for protection of potato from walking adult Colorado potato beetles (Coleoptera: Chrysomelidae). Journal of Economic Entomology 87, 1325-1331

Bostan H, Guclu C, Ozturk E, Ozdemir I, Ilbagi H (2006) Influence of aphids on the epidemiology of potato virus diseases (PVY, PVS and PLRV) in the high altitude areas of Turkey. Pakistan Journal of Biological Sciences 9, 759-765

Caillaud CM, Di Pietro JP, Chaubet B, Pierre JS (1995) Application of discriminant analysis to electrical penetration graphs of the aphid Sitobion avenae feeding on resistant and susceptible wheat. Journal of Applied Entomology 119, 103-106

Campos RG (1976) Control químico del 'minador de hojas y tallos de la papa' (Scrobipalpula absoluta Meyrick) en el valle del Cañete. Revista Peruana de Entomologia 19, 102-106

Cantelo WW, Douglass LW, Sanford LL, Sinden SL, Deahl KL (1987) Measuring resistance to the Colorado potato beetle (Coleoptera: Chrysomelidae) in potato. Journal Entomological Science 22, 245-252

Carter CD (1987) Screening Solanum germplasm for resistance to Colorado potato beetle. American Potato Journal 64, 563-568

Casagrande RA (1982) Colorado potato beetle resistance in wild potato, Solanum berthaultii. Journal Economic Entomology 75, 368-372

Castanera P, Steffens JC, Tingey WM (1996) Biological performance of Colorado potato beetle larvae on potato genotypes with differing levels of polyphenol oxidase. Journal of Chemical Ecology 22, 91-101

Chen JQ, Rahbé Y, Delobel B, Sauvion N, Guillaud J, Febvay G (1997) Melon resistance to the aphid Aphis gossypii: Behavioural analysis and chemical correlations with nitrogenous compounds. Entomologia Experimentalis et Applicata 85, 33-44

Chen Q, Li HY, Shi YZ, Beasley D, Bizimungu B, Goettel MS (2008) Development of an effective protoplast fusion system for production of new potatoes with disease and insect resistance using Mexican wild potato species as gene pools. Canadian Journal of Plant Science 88, 611-619

Chen Q, Lynch D, Platt HW, Li HY, Shi Y, Li HJ, Beasley D, Rakosy-Tican L, Theme R (2004) Interspecific crossability and cytogenetic analysis of sexual progenies of Mexican wild diploid 1EBN species Solanum pinnatisectum and S. cardiophyllum. American Journal of Potato Research 81, 159-169

Coleman WK (2000) Physiological ageing of potato tubers: A review. Annals of Applied Biology 137, 189-199

Coll M, Yuval B (2004) Larval food plants affect flight and reproduction in an oligophagous insect herbivore. Environmental Entomology 33, 1471-1476

Cutter EG (1992) Structure and development of the potato plant. In: Harris P (Ed) The Potato Crop: The Scientific Basis for Improvement $\left(2^{\text {nd }}\right.$ Edn), Chapman and Hall, London, UK, pp 65-146

Dangles O, Carpio C, Barragan AR, Zeddam J-L, Silvain J-F (2008) Temperature as a key driver of ecological sorting among invasive pest species in the tropical Andes. Ecological Applications 18, 1795-1809

Dangles O, Mesias V, Crespo-Perez V, Silvain J-F (2009) Crop damage increases with pest species diversity: Evidence from potato tuber moths in the tropical Andes. Journal of Applied Ecology 46, 1115-1121

Das GP, Magallona ED, Raman KV, Adalla CB (1993a) Growth and development of the potato tuber moth, Phthorimaea operculella (Zeller), on resistant and susceptible potato genotypes in storage. Philippines Entomologist 9, 1527

Das GP, Magallona ED, Raman KV, Adalla CB (1993b) Screening different potato genotypes under different population pressures for resistance to the potato tuber moth, Phthorimaea operculella (Zeller), in storage. Philippines Entomologist 9, 7-14 
Das PS, Raina R, Prasad AR, Sen A (2007) Electroantennogram responses of the potato tuber moth, Phthorimaea operculella (Lepidoptera: Gelechiidae) to plant volatiles. Journal of Biosciences 32, 339-349

Davis JA, Radcliffe EB, Ragsdale DW (2007) Resistance to green peach aphid, Myzus persicae (Sulzer), and potato aphid, Macrosiphum euphorbiae (Thomas), in potato cultivar. American Journal of Potato Research 84, 259-269

Deedat TD, Ellis CR, West RJ (1983) Life-history of the potato stem borer (Lepidoptera, Noctuidae) in Ontario. Journal of Economic Entomology 76, 1033-1037

de Souza VQ, Pereira ADS, da Silva GO, de Carvalho FIF (2006) Correlations between insect resistance and horticultural traits in potatoes. Crop Breeding and Applied Biotechnology 6, 278-284

Devonshire AL, Field LM, Foster SP, Moores GD, Williamson MS, Blackman RL (1998) The evolution of insecticide resistance in the peach-potato aphid, Myzus persicae. Philosophical Transactions of the Royal Society B. Biological Sciences 353, 1677-1684

Difonzo CD, Ragsdale DW, Radcliffe EB, Gudmestad NC, Secor GA (1997) Seasonal abundance of aphid vectors of Potato virus $Y$ in the Red River Valley of Minnesota and North Dakota. Journal of Economic Entomology $\mathbf{9 0}$, 824-831

Dimock MB, Lapointe SL, Tingey WM (1986) Solanum cardenasii: A new source of potato resistance to the Colorado potato beetle (Coleoptera: Chrysomelidae). Journal of Economic Entomology 79, 1269-1275

Dimock MB, Tingey WM (1987) Mechanical interaction between larvae of the Colorado potato beetle and glancular trichomes of Solanum berthaultii. American Potato Journal 64, 507-516

Dimock MB, Tingey WM (1988) Host acceptance behavior of Colorado potato beetle larvae influenced by potato glandular trichomes. Physiological Entomology 13, 399-406

Dixon AFG (1998) Aphid Ecology, Chapman and Hall, London, UK, 300 pp

Douglas AE (2006) Phloem-sap feeding by animals: Problems and solutions Journal of Experimental Botany 57, 747-754

Douglas AE (2003) Buchnera bacteria and other symbionts of aphids. In: Bourtzis K, Miller TA (Eds) Insect Symbiosis, CRC Press, Boca Raton, FL, USA, pp 23-38

Dreyer DL, Campbell BC (1987) Chemical basis for host-plant resistance to aphids. Plant, Cell and Environment 10, 353-361

Ecole CC, Picanço MC, Guedes RNC, Brommonschenkel SH (2001) Effect of cropping season and possible compounds involved in the resistance of Lycopersicon hirsutum f. typicum to Tuta absoluta (Meyrick)(Lep., Gelechiidae). Journal of Applied Entomology 125, 193-200

Estrada N, Valencia L (1988) Desarrollo de cultivares de pap resistentes a la palomilla Phthorimaea operculella (Zeller), en Colombia. Revista Latinoamericana de la Papa 1, 64-73

Fenemore PG (1978) Oviposition of potato tuber moth, Phthorimaea operculella Zell. (Lepidoptera: Gelechiidae): The physical nature of the oviposition substrate. New Zealand Journal of Zoology 5, 591-599.

Fenemore PG (1980) Susceptibility of potato cultivars to the potato tuber moth, Phthorimaea operculella (Zell.)(Lepidoptera: Gelechiidae). New Zealand Journal of Agricultural Research 23, 539-546

Figueira LK, Fernando LM (2004) Predator:prey ratios of Chrysoperla externa (Hagen) (Neuroptera: Chrysopidae) for the control of greenbug in sorghum genotypes. Neotropical Entomology 33, 447-450

Flanders KL, Arnone S, Radcliffe EB (1999) The Potato: genetic resources and insect resistance. In: Clement SL, Quisenberry SS (Eds) Global Plan Genetic Resources for Insect-Resistant Crops, CRC Press, Boca Raton, FL, USA, pp 207-239

Flanders KL, Hawkes JG, Radcliffe EB, Lauer FI (1992) Insect resistance in potatoes: Sources, evolutionary relationship, morphological and chemical defenses, and ecogeographical associations. Euphytica 61, 83-111

Flanders KL, Radcliffe EB, Hawkes JG (1997) Geographic distribution of insect resistance in potatoes. Euphytica 93, 2001-2221

Foot MA (1975) Cultural practices in relation to infestation of potato crops by the potato tuber moth. II. Effect of seed depth, re-moulding, pre-harvest defoliation and delayed harvest. New Zealand Journal of Experimental Agriculture 4, 121-124

Franca FH, Plaisted RL, Roush RT, Via S, Tingey WM (1994) Selection response of the Colorado potato beetle for adaptation to the resistant potato, Solanum berthaultii. Entomologia Experimentalis et Applicata 73, 101-109

Franca FH, Tingey WM (1994) Solanum berthaultii Hawkes affects the digestive system, fat body and ovaries of the Colorado potato beetle. American Potato Journal 71, 405-411

Gibson RW (1971a) Glandular hairs providing resistance to aphids in certain wild potato species. Annals of Applied Biology 68, 113-119

Gibson RW (1971b) The resistance of three Solanum species to Myzus persicae, Macrosiphum euphorbiae and Aulacorthum solani (Aphidae: Homoptera). Annals of Applied Biology 68, 245-251

Gibson RW (1976) Glandular hairs are a possible means of limiting aphid damage to the potato crop. Annals of Applied Biology 82, 143-146

Gibson RW (1976b) Glandular hairs on Solanum polyadenium lessen damage by the Colorado beetle. Annals of Applied Biology 82, 147-150

Gibson RW (1979) The geographical distribution, inheritance and pest-resistance properties of sticky-tipped foliar hairs on potato species. Potato Research 22, 223-236
Gibson RW, Pickett JA (1983) Wild potato repels aphids by release of aphid alarm pheromone. Nature 302, 608-609

Gibson RW, Plumb RT (1977) Breeding plants for resistance to aphid infestation. In: Harris KF, Maramorosch K (Eds) Aphids and Virus Vectors, Academic Press, New York, USA, pp 473-500

Goggin FL, Williamson VM, Ullman DE (2001) Variability in the response of Macrosiphum euphorbiae and Myzus persicae (Hemiptera: Aphididae) to the tomato resistance gene Mi. Environmental Entomology 30, 101-106

Gooderham J, Bailey PCE, Gurr GM, Baggen LR (1998) Sub-lethal effects of foliar pubescence on the egg parasitoid Copidosoma koehleri and influence on parasitism of potato tuber moth, Phthorimaea operculella. Entomologia Experimentalis et Applicata 87, 115-118

Gregory P, Tingey WM, Ave DA, Bouthyette PY (1986) Potato glandular trichomes: A physicochemical defense mechanism against insects. In: Green NB, Hedin PA (Eds) Natural Resistance of Plants to Pests; Roles of Allelochemicals, American Chemical Society, Washington DC, USA, pp 160-167

Groden E, Casagrande RA (1986) Population dynamics of the Colorado potato beetle, Leptinotarsa decemlineata (Coleoptera: Chrysomelidae), on Solanum berthaultii. Journal of Economic Entomology 79, 91-97

Gurr GM, Symington CA (1998) Resistance of the potato tuber moth, Phthorimaea operculella (Zeller)(Lepidoptera: Gelechiidae), in potato (Solanum tuberosum ssp. tuberosum L.) tubers. Australian Journal of Entomology 37 , 49-51

Gurr GM, McGrath D (2002) Foliar pubescence and resistance to potato tuber moth, Phthorimaea operculella, in Lycopersicon hirsutum. Entomologia Experimentalis et Applicata 103, 35-41

Gurr GM, Symington CA (1998) Resistance to the potato tuber moth, Phthorimaea operculella (Zeller)(Lepidoptera: Gelechiidae), in potato (Solanum tuberosum ssp. tuberosum L.) tubers. Australian Journal of Entomology 37, 49-51

Hanzlik MW, Kennedy GG, Sanders DC, Monks DW (1997) Response of European corn borer (Ostrinia nubilalis, Hubner) to two potato hybrids selected for resistance to Colorado potato beetle. Crop Protection 16, 487-490

Hare JD (1990) Ecology and management of the Colorado potato beetle. Annual Review of Entomology 35, 81-100

Hawkes JG (1958) Significance of wild species and primitive forms for potato breeding. Euphytica 7, 257-270

Horgan FG, Quiring DT, Lagnaoui A, Pelletier Y (2007a) Variable responses of tuber moth to the leaf-trichomes of wild potatoes. Entomologia Experimentalis et Applicata 125, 1-12

Horgan FG, Quiring DT, Lagnaoui A, Pelletier Y (2009a) Effects of altitude of origin on trichome-mediated antiherbivore resistance in wild Andean potatoes. Flora 204, 49-62

Horgan FG, Quiring DT, Lagnaoui A, Pelletier Y (2009b) Trade-off between foliage and tuber resistance to Phthorimaea operculella in two wild potatoes. Entomologia Experimentalis et Applicata 131, 130-137

Horgan FG Quiring DT, Lagnaoui A, Salas AR, Pelletier Y (2007b) Periderm- and cortex-based resistance to tuber-feeding Phthorimaea operculella in two wild potato species. Entomologia Experimentalis et Applicata $\mathbf{1 2 5}$ 249-258

Horgan FG, Quiring DT, Lagnaoui A, Salas AR, Pelletier Y (2010) Variations in resistance against Phthorimaea operculella in wild potato tubers. Entomologia Experimentalis et Applicata 137, 269-279

Horton DR, Chauvin RL, Hinojosa T, Larson S, Murphy C, Biever KD (1997) Mechanisms of resistance to Colorado potato beetle in several potato lines and correlation with defoliation. Entomologia Experimentalis et Applicata 82, 239-246

Jackson SA, Hanneman RE (1999) Crossability between cultivated and wild tuber-bearing and non-tuber-bearing Solanums. Euphytica 109, 51-67

Jansky S, Austin-Phillips S, McCarthy C (1999) Colorado potato beetle resistance in somatic hybrids of diploid interspecific Solanum clones. HortScience 34, 922-927

Jansky SH, Simon R, Spooner DM (2009) A test of taxonomic predictivity: Resistance to the Colorado potato beetle in wild relatives of cultivated potato. Journal of Economic Entomology 102, 422-431

Kalazich JC, Plaisted RL (1991) Association between trichome characters and agronomic traits in Solanum tuberosum (L.) x S. berthaultii (Hawkes) hybrids. American Potato Journal 68, 833-847

Karlsson MF, Birgersson G, Cotes Prado AM, Bosa F, Bengtsson M, Witzgall P (2009) Plant odor analysis of potato: Response of Guatemalan moth to above- and belowground potato volatiles. Journal of Agricultural and Food Chemistry 57, 5903-5909

Kennedy GG (1983) Effects of European corn borer (Lepidoptera: Pyralidae) damage on yields of spring-grown potatoes. Journal of Economic Entomology 76, 316-322

Kroschel K, Koch W (1994) Studies on the population dynamics of the potato tuber moth (Phthorimaea operculella Zell. (Lep., Gelechiidae) in the Republic of Yemen. Journal of Applied Entomology 188, 327-341

Lafta AM, Lorenzen JH (2000) Influence of high temperature and reduced irradiance on glycoalkaloid levels in potato leaves. Journal of the American Society for Horticultural Science 125, 563-566

Landis BJ, Powell DM, Fox L (1972) Populations of aphids on named varieties of Irish potatoes. American Potato Journal 49, 63-69

Landolt PJ (2001) Moth experience and not plant injury affected female cab- 
bage looper moth (Lepidoptera: Noctuidae) orientation to potato plants. Florida Entomologist 84, 243-249

Lapointe SL, Tingey WM (1984) Feeding response of the green peach aphid (Homoptera: Aphididae) to potato glandular trichomes. Journal of Economic Entomology 77, 386-389

Lapointe SL, Tingey WM (1986) Glandular trichomes of Solanum neocardenasii confer resistance to green peach aphid (Homoptera: Aphididae). Journal of Economic Entomology 79, 1264-1268

Leite GLD, Picanço M, Guedes RNC, Zanuncio JC (2001) Role of plant age in the resistance of Lycopersicon hirsutum f. glabratum to the tomato leafminer Tuta absoluta (Lepidoptera: Gelechiidae). Scientia Horticulturae 89, 103-113

Le Roux V, Campan EDM, Dubois F, Vincent C, Giordanengo P (2007) Screening for resistance against Myzus persicae and Macrosiphum euphorbiae among wild Solanum. Annals of Applied Biology 151, 83-88

Le Roux V, Dugravot S, Campan E, Dubois F, Vincent C, Giordanengo P (2008) Wild Solanum resistance to aphids: Antixenosis or antibiosis? Journal of Economic Entomology 101, 584-591

Lorenzen JH, Balbyshev NF (1997) ND2858-1: A useful source of resistance to the Colorado potato beetle. American Potato Journal 74, 331-335

Lorenzen JH, Balbyshev NF, Lafta AM, Casper H, Tian X, Sagredo B (2001) Resistant potato selections contain leptine and inhibit development of the Colorado potato beetle (Coleoptera: Chrysomelidae). Journal of Economic Entomology 94, 1260-1267

Lyytinen A, Lindstrom L, Mappes J, Julkunen-Tiitto R, Fasulati SR, Tiilikkala K (2007) Variability in host plant chemistry: Behavioural responses and life-history parameters of the Colorado potato beetle (Leptinotarsa decemlineata). Chemoecology 17, 51-56

Malakar R, Tingey WM (1999) Resistance of Solanum berthaultii foliage to potato tuberworm (Lepidoptera: Gelechiidae). Journal of Economic Entomology 92, 497-502

Malakar R, Tingey WM (2000) Glandular trichomes of Solanum berthaulti and its hybrids with potato deter oviposition and impair growth of potato tuber moth. Entomologia Experimentalis et Applicata 94, 249-257

Malakar-Kuenen R, Tingey WM (2006) Aspects of tuber resistance in hybrid potatoes to potato tuber worm. Entomologia Experimentalis et Applicata 120, 131-137

Mehlenbacher SP, Plaisted RL, Tingey WM (1984) Heritability of trichome density and droplet size in interspecific potato hybrids and relationship to aphid resistance. Crop Science 24, 320-322

Metspalu L, Hiiesaar K, Kuusik A, Joudu J, Lohmus A (2000) Host-plant selection by Colorado potato beetle (Leptinotarsa decemlineata Say) between three cultivars of potato (Solanum tuberosum). Transactions of the Estonian Agricultural University 1, 132-135

Miyasaki M (1987) Forms and morphs of aphids. In: Minks AK, Harrewijn P (Eds) Aphids: Their Biology, Natural Enemies and Control, Elsevier, Amsterdam, The Netherland, pp 27-47

Mndolwa D, Bishop G, Corsini D, Pavek J (1984) Resistance of potato clones to the green peach aphid and potato leafroll virus. American Potato Journal 61, 713-722

Mulatu B, Applebaum SW, Coll M (2004) A recently acquired host plant provides an oligophagous insect herbivore with enemy-free space. Oikos 107 231-238

Musmeci S, Ciccoli R, Di Gioia V, Sonnino A, Arnoné S (1997). Leaf effects of wild potato species of Solanum and interspecific hybrids on growth and behavior of the potato tuber moth, Phthorimaea operculella Zeller. Potato Research 40, 417-430

Nabi MN (1984) Resistance of potato lines to potato moth, Phthorimaea operculella. Report to New Zeland Department of Agriculture, pp 122-123

Nandy S, Chen Q, Yang J, Beasley D, Li H, Goettel MS (2008) Use of a detached leaf screening method for segregating Colorado potato beetle (Leptinotarsa decemlineata Say) resistant Solanum hybrid lines. Canadian Journal of Plant Science 88, 633-638

Nault BA, Speese III J, Kennedy GG, Linduska J, Dively GP (2001) Response of potato tuber yield to stem injury by European corn borer (Lepidoptera: Crambidae) in the Mid-Atlantic United States. Journal of Economic Entomology 94, 1162-1169

Neal JJ, Tingey WM, Steffebs JC (1990) Sucrose esters of carboxylic acids in glandular trichomes of Solanum berthaultii deter settling and probing by green peach aphid. Journal of Chemical Ecology 16, 487-497

Neal JJ, Plaisted RL, Tingey WM (1991) Feeding behaviour and survival of Colorado potato beele, Leptinotarsa decemlineata (Say), larvae on Solanum berthaultii Hawkes and an F6 S. tuberosum L. X S. berthaultii Hybrid. American Potato Journal 68, 649-658

Neal JJ, Steffens JC, Tingey WM (1989) Glandular trichomes of Solanum berthaultii and reistance to the Colorado potato beetle. Entomologia Experimentalis et Applicata 51, 133-140

Niemeyer HM, Givovich A, Copaja V (1993) Hydroxamic acids: Chemical defences in wheat against aphids. In: Corey SA (Ed) Pest Control and Sustainable Agriculture, CSIRO, Canberra, Australia, pp 39-43

Novy RG, Nasruddin A, Ragsdale DW, Radcliffe EB (2002) Genetic resistances to potato leafroll virus, potato virus $\mathrm{Y}$, and green peach aphid in progeny of Solanum etuberosum. American Journal of Potato Research 79, 9-18

Ochoa CM (1980) A new tuber-bearing Solanum potentially useful for breeding for aphid resistance. American Potato Journal 57, 387-390

Ojero MFO, Muerke JM (1985) Resistance of four potato varieties to the potato tuber moth, Phthorimaea operculella (Zell.) in storage. Insect Science Applications 6, 205-207

Ortíz R, Iwanaga M, Raman KV, Palacios M (1990) Breeding for resistance to potato tuber moth, Phthorimaea operculella (Zeller), in diploid potatoes. Euphytica 50, 119-125

Osman SF, Sinden SL, Irwin P, Deahl K, Tingey WM (1991) Solanocardinol: A steroidal alkaloid from Solanum neocardenasii. Phytochemistry 30, 3161 3163

Painter RH (1951) Insect Resistance in Crop Plants, MacMillian, New York, USA, $170 \mathrm{pp}$

Palacios M, Tenorio J, Vera M, Zevallos F, Lagnaoui A (1999) Population dynamics of the Andean potato tuber moth, Symmetrischema tangolias (Gyen), in three different agro-ecosystems in Peru. CIP Program Report 1997-1998, Lima, Peru, pp 153-169

Panda N, Khush GS (1995) Host Plant Resistance to Insects, CABI, Wallingford, UK, $431 \mathrm{pp}$

Parihar SBS, Chandla VK (1995) Reaction of potato varieties/hybrids to tuber-moth Phthorimaea operculella. Journal of the Indian Potato Association 22, 90-91

Pelletier Y (1990) The role of the color of the substratum on the initiation of the probing behavior in Myzus persicae (Sulzer) and Macrosiphum euphorbiae (Thomas) (Homoptera: Aphididae). Canadian Journal of Zoology 68, 694698

Pelletier Y (1995) Recognition of conspecific eggs by female Colorado potato beetles (Coleoptera: Chrysomelidae). Environmental Entomology 24, 875878

Pelletier Y, Clark C (2004) Use of reciprocal grafts to elucidate mode of resistance to Colorado potato beetle (Leptinotarsa decemlineata (Say)) and potato aphid (Macrosiphum euphorbiae (Thomas)) in six wild Solanum species. American Journal of Potato Research 81, 341-346

Pelletier Y, Dutheil J (2006) Behavioural responses of the Colorado potato beetle to trichomes and leaf surface chemicals of Solanum tarijense. Entomologia Experimentalis et Applicata 120, 125-130

Pelletier Y, Giguère MA (2009) Effect of manipulations on the host selection behavior of Sitobion avenae (Homoptera: Aphididae). Journal of Insect Behavior 22, 165-171

Pelletier Y, Smilowitz Z (1990) Effect of trichome B exudate of Solanum berthaultii Hawkes on consumption by the Colorado potato beetle, Leptinotarsa decemlineata (Say). Journal of Chemical Ecology 16, 1547-1555

Pelletier Y, Smilowitz Z (1991) Biological and genetic study on the utilization of Solanum berthaultii Hawkes by the Colorado potato beetle (Leptinotarsa decemlineata (Say)). Canadian Journal of Zoology 69, 1280-1288

Pelletier Y, Smilowitz Z (1991) Feeding behavior of the adult Colorado potato beetle, Leptinotarsa decemlineata (Say), on Solanum berthaultii Hawkes. Canadian Entomologist 123, 219-230

Pelletier Y, Tai GCC (2001) Genotypic variability and mode of action of Colorado potato beetle (Coleoptera: Chrysomelidae) resistance in seven Solanum species. Journal of Economic Entomology 94, 572-578

Pelletier Y, Clark C, De Koeyer D (2007) Level and genetic variability of resistance to the Colorado potato beetle (Leptinotarsa decemlineata (Say)) in wild Solanum species. American Journal of Potato Research 84, 143-148

Pelletier Y, Clark C, Tai GC (2001) Resistance of three wild tuber-bearing potatoes to the Colorado potato beetle. Entomologia Experimentalis et Applicata 100, 31-41

Pelletier Y, Grondin G, Maltais P (1999) Mechanism of resistance to the Colorado potato beetle in wild Solanum species. Journal of Economic Entomology 92, 708-713

Pelletier Y, Pompon J, Dexter P, Quiring D (2010) Biological performance of Myzus persicae and Macrosiphum euphorbiae (Homoptera: Aphididae) on seven wild Solanum species. Annals of Applied Biology 156 (3), 329-336

Pereyra PC, Sánchez NE (2006) Effect of two Solanaceous plants on developmental and population parameters of the tomato leaf miner, Tuta absoluta (Meyrick)(Lepidoptera: Gelechiidae). Neotropical Entomology 35, 671-676

Plaisted RL, Tingey MW, Steffens JC (1992) The germplasm release of NYL 235-4, a clone with resistance to Colorado potato beetle. American Potato Journal 63, 843-846

Pompon J, Quiring D, Giordanengo P, Pelletier Y (2010a) Resistance mechanism of wild Solanum species to Macrosiphum euphorbiae (Thomas) and Myzus persicae (Sulzer).. Entomologia Experimentalis et Applicata in press

Pompon J, Quiring D, Giordanengo P, Pelletier Y (2010b) Characterization of Solanum chomatophilum resistance to two aphid potato pests, Macrosiphum euphorbiae (Thomas) and Myzus persicae (Sulzer). Crop Protection 29, 891-897

Pompon J, Quiring D, Giordanengo P, Pelletier Y (2010c) Role of xylem consumption on osmoregulation in Macrosiphum euphorbiae (Thomas). Journal of Insect Physiology 56, 610-615

Pompon J (2010) Performance influenced by host-plant selection and feeding behaviour in aphids. PhD thesis, University of New Brunswick, $146 \mathrm{pp}$

Ponder KL, Pritchard J, Harrington R, Bale JS (2000) Difficulties in location and acceptance of phloem sap combined with reduced concentration of phloem amino acids explain lowered performance of the aphid Rhopalosiphum padi on nitrogen deficient barley (Hordeum vulgare) seedlings. Ento- 
mologia Experimentalis et Applicata 97, 203-210

Povolny D, Hula V (2004) A new potato pest invading southwestern Europe, the Guatemalan potato tuber moth Scrobilpalpopsis solanivora (Lepidoptera: Gelechiidae). Entomologia Generalis 27, 155-168

Powell G, Tosh CR, Hardie J (2006) Host plant selection by aphids: Behavioral, evolutionary, and applied perspectives. Annual Review of Entomology 51, 309-330

Powell G, Hardie J, Pickett J-A (1995) Behavioural evidence for detection of the repellent polygodial by aphid antennal tip sensilla. Physiological Entomology 20, 141-146

Prado E, Tjallingii WF (1999) Effects of experimental stress factors on probing behaviour by aphids. Entomologia Experimentalis et Applicata 90, 289300

Quinn GP, Keough MJ (2002) Experimental Design and Data Analysis for Biologists, Cambridge University Press, Cambridge, UK, 560 pp

Quisumbing AR, Lauer FI, Radcliffe EB (1970) Resistance to green peach aphid, Myzus persicae (Sulzer), in hybrids from wild tuber-bearing Solanum species. Proceedings of North Central Branch - E.S.A. 25, 103-105

Radcliffe EB (1982) Insect pests of potato. Annual Review of Entomology 27, 173-204

Radcliffe EB, Lauer FI (1968) Resistance to Myzus persicae (Sulzer), Macrosiphum euphorbiae (Thomas) and Empoasca fabae (Harris) in the wild tuberbearing Solanum (Tourn.) L. species. University of Minnesota Agricultural Experiment Station Technical Bulletin 259, 2-27

Radcliffe EB, Lauer FI (1970a) Aphid resistance in the wild tuber-bearing Solanum (Tourn.) L. species. Proceeding of North Central Branch - E.S.A. 25 101-105

Radcliffe EB, Lauer FI (1970b) Further studies on resistance to green peach aphid and potato aphid in the wild tuber bearing Solanum species. Journal of Economic Entomology 63, 110-114

Radcliffe EB, Lauer FI (1971a) An appraisal of aphid resistant tuber-bearing Solanum germplasm. University of Minnesota Agricultural Experiment Station Technical Bulletin 286, 2-24

Radcliffe EB, Lauer FI (1971b) Resistance to green peach aphid and potato aphid in introductions of wild tuber-bearing Solanum species. Journal of Economic Entomology 64, 1260-1266

Radcliffe EB, Lauer FI, Lee MH, Robinson DP (1981) Evaluation of the United States potato collection for resistance to green peach aphid and potato aphid. University of Minnesota Agricultural Experiment Station Technical Bulletin 331, $42 \mathrm{pp}$

Radcliffe EB, Lauer FI, Stucker RE (1974) Stability of green peach aphid resistance in tuber-bearing Solanum introductions and its effect on screening procedures. Environmental Entomology 3, 1022-1026

Radcliffe EB, Tingey W-M, Gibson RW, Valencia L, Raman KV (1988) Stability of green peach aphid (Homoptera: Aphididae) resistance in wild potato species. Journal of Economic Entomology 81, 361-367

Raman KV, Palacios M (1982) Screening potato for resistance to potato tuberworm. Journal of Economic Entomology 75, 47-49

Raman KV (1988) Control of potato tuber moth Phthorimaea operculella with sex pheromones in Peru. Agriculture, Ecosystems and Environment 21, 85-99

Ramirez CC, Niemeyer HM (1999) Salivation into sieve elements in relation to plant chemistry: The case of the aphid Sitobion fragariae and the wheat, Triticum aestivum. Entomologia Experimentalis et Applicata 91, 111-114

Rêgo Lopes MT, Vendramim JD (2001) Resistência de genótipos de batata a Phthorimaea operculella (Zeller). Scientia Agricola 58, 235-239

Sagredo B, Lafta A, Casper H, Lorenzen J (2006) Mapping of genes associated with leptine content of tetraploid potato. Theoretical and Applied Genetics 114, 131-142

Sams DW, Lauer FI, Radcliffe EB (1976) Breeding behaviour of resistance to green peach aphid in tuber-bearing Solanum germplasm. American Potato Journal 53, 23-29

Sanford LL, Kowalski SP, Ronning CM, Deahl KL (1998) Leptines and other glycoalkaloids in tetraploid Solanum tuberosum x Solanum chacoense F2 hybrid and backcross families. American Journal of Potato Research 75, $167-172$

Shannag HK, Obeidat WM (2008) Interaction between plant resistance and predation of Aphis fabae (Homoptera: Aphididae) by Coccinella septempunctata (Coleoptera: Coccinellidae). Annals of Applied Biology 152, 331-337

Shelton AM, Wyman JA (1979) Potato tuberworm damage to potatoes under different irrigation and cultural practices. Journal of Economic Entomology 72, 261-264

Sikinyi E, Hannapel SJ, Imerman PM, Stahr HM (1997) Novel mechanism for resistance to Colorado potato beetle (Coleoptera:Chrysomelidae) in wild Solanum species. Journal Economic Entomology 90, 689-696

Sileshi G, Teriessa J (2001) Tuber damage by potato tuber moth, Phthorimaea operculella Zeller (Lepidoptera: Gelechiidae) in the field in eastern Ethiopia. International Journal of Pest Management 47, 109-113

Simon JC, Carré S, Boutin M, Prunier-Leterme N, Sabater-Mun B, Latorre A, Bournoville R (2003) Host-based divergence in populations of the pea aphid: Insights from nuclear markers and the prevalence of facultative symbionts. Proceedings of the Royal Society B: Biological Sciences 270, 1703-1712
Sinden SL, Sanford LL, Cantelo WW, Deahl KL (1986) Leptine glycoalkaloids and resistance to the Colorado potato beetle (Coleoptera: Chrysomelidae) in Solanum chacoense. Environmental Entomology 15, 1057-1062

Sinden SL, Cantelo WW, Sanford LL, Deahl KL (1991) Allelochemically mediated host resistance to the Colorado potato beetleetle, Leptinotarsa decemlineata (Say) (Coleoptera: Chrysomelidae). Memoirs of the Entomological Society of Canada 157, 19-28

Sinden SL, Sanford LL, Cantelo WW, Deahl KL (1988) Bioassays of segregating plants - A strategy for studying chemical defenses. Journal of Chemical Ecology 14, 1941-1950

Smilyanets V, Korol T, Smilyanets P (2007) Microevolutionary processes in a population of the Colorado potato beetle (Leptinotarsa decemlineata Say.) at feeding by various cultivars of the potato. Archives of Phytopathology and Plant Protection 40, 169-175

Smith CM, Quisenberry SS (1994) Value and use of plant resistance to insect in integrated crop management. Journal of Agricultural Entomology 1109, 189-190

Sokal RR, Rohlf FJ (1995) Biometry: The Principles and Practice of Statistics in Biological Research, New York, 887 pp

Spooner DM, Fajardo D, Bryan GJ (2007) Species limits of Solanum berthaultii Hawkes and $S$. tarijense Hawkes and the implications for species boundaries in Solanum sect. Petota. Taxon 56, 987-999

Steffens JC, Walters DS (1991) Biochemical aspects of glandular trichomemediated insect resistance in the Solanaceae. In Hedin PA (Ed) Naturally Occuring Pest Bioregulators, American Chemical Society, Washington, DC, USA, pp 136-143

Thieme R, Darsow U, Gavrilenko T, Dorokhov D, Tiemann H (1997) Production of somatic hybrids between $S$. tuberosum L. and late blight resistant Mexican wild potato species. Euphytica 97, 189-200

Thieme R, Rakosy-Tican E, Gavrilenko T, Antonova O, Schubert J, Nachtigall M, Heimbach U, Thieme T (2008) Novel somatic hybrids (Solanum tuberosum L. + Solanum tarnii) and their fertile $\mathrm{BC} 1$ progenies express extreme resistance to potato virus $\mathrm{Y}$ and late blight. Theoretical and Applied Genetics 116, 691-700

Thompson A, Farnsworth B, Gudmestad N, Secor G, Preston D, Sowokinos J, Glynn M, Hatterman-Valenti H (2008) Dakota Diamond: An exceptionally high yielding, cold chipping potato cultivar with long-term storage potential. American Journal of Potato Research 85, 171-182

Tingey WM (1984) Glycoalkaloids as pest resistance factors. American Potato Journal 61, 157-167

Tingey WM (1985) Plant defensive mechanisms against leafhoppers. In: Nault LR, Rodriguez JG (Eds) The Leafhoppers and Planthoppers, John Wiley and Sons, Brisbane, Australia, pp 217-234

Tingey WM, Laubengayer JE (1981) Defense against the green peach aphid and potato leafhopper by glandular trichomes of Solanum berthaultii. Journal of Economic Entomology 74, 721-725

Tingey WM, Yencho GC (1994) Insect resistance in potato: A decade of progress. In: Zehnder GW, Powelson ML, Jackson RK, Raman KV (Eds) Advances in Potato Pest Biology and Management, American Phytopathological Society, St. Paul, USA, pp 405-425

Tingey WM, Plaisted RL, Laubengayer JE, Mehlenbacher SA (1982) Green peach aphid resistance by glandular trichomes in Solanum tuberosum $\times S$. berthaultii. American Potato Journal 59, 241-251

Tingey WM, Sinden SL (1982) Glandular pubescence, glycoalkaloid composition, and resistance to the green peach aphid, potato leafhopper, and potato fleabeetle in Solanum berthaultii. American Potato Journal 59, 95-106

Tjallingii WF (1994) Sieve element acceptance by aphids. European Journal of Entomology 91, 47-52

Tjallingii WF (1995) Aphid-plant interactions: What goes on in the depth of the tissues? Proceedings of Experimental and Applied Entomology 6, 189-200

Tjallingii WF (2006) Salivary secretions by aphids interacting with proteins of phloem wound responses. Journal of Experimental Botany 57, 739-745

Torka M (1950) Breeding potatoes with resistance to the Colorado beetle. American Potato Journal 27, 263-271

Traynier RMM (1975) Field and laboratory studies of the oviopsition by the potato moth, Phthorimaea operculella Zell. Bulletin of Entomological Research 65, 391-398

Tyner DN, Hocart MJ, Lennard JH, Graham DC (1997) Periderm and lenticle characterization in relation to potato cultivar, soil moisture and maturity. Potato Research 40, 181-190

Valencia L (1984) Mechanisms of resistance to potato moth oviposition on foliage. In: Integrated Pest Management, Report of the XXII Planning Conference on Integrated Pest Management, Lima, Peru, pp 161-187

Valkonen JPT, Brigneti G, Pehu E (1992) Resistance to Myzus persicae (Sulz.) in wild potatoes of the series Etuberosa. Acta Agriculturae Scandinavica Section B: Soil and Plant Science 42, 118-127

van Emden HF, Eastop VF, Hughes RS, Way MJ (1969) The ecology of Myzus persicae. Annual Review of Entomology 14, 1113-1119

Varela LG, Bernays EA (1988) Behavior of newly hatched potato tuber moth larvae, Phthorimaea operculella Zell. (Lepidoptera: Gelechiidae), in relation to their host plants. Journal of Insect Behavior 1, 261-275 